\title{
Assessment of the association between dust storms and COVID-19 infection rate in southwest Iran
}

\author{
Parya Broomandi ${ }^{1,2} \cdot$ Byron Crape $^{3} \cdot$ Ali Jahanbakhshi $^{4} \cdot$ Nasime Janatian $^{5,6} \cdot$ Amirhossein Nikfal $^{7} \cdot$ Mahsa Tamjidi $^{8}$. \\ Jong R. Kim ${ }^{1} \cdot$ Nick Middleton $^{9} \cdot$ Ferhat Karaca $^{1,10}$
}

Received: 21 September 2021 / Accepted: 14 December 2021 / Published online: 21 January 2022

(c) The Author(s), under exclusive licence to Springer-Verlag GmbH Germany, part of Springer Nature 2021

\begin{abstract}
This study assesses a plausible correlation between a dust intrusion episode and a daily increase in COVID-19 cases. A surge in COVID-19 cases was observed a few days after a Middle East Dust (MED) event that peaked on $25^{\text {th }}$ April 2020 in southwest Iran. To investigate potential causal factors for the spike in number of cases, cross-correlations between daily combined aerosol optical depths (AODs) and confirmed cases were computed for Khuzestan, Iran. Additionally, atmospheric stability data time series were assessed by covering before, during, and after dust intrusion, producing four statistically clustered distinct city groups. Groups 1 and 2 had different peak lag times of 10 and 4-5 days, respectively. Since there were statistically significant associations between AOD levels and confirmed cases in both groups, dust incursion may have increased population susceptibility to COVID-19 disease. Group 3 was utilized as a control group with neither a significant level of dust incursion during the episodic period nor any significant associations. Group 4 cities, which experienced high dust incursion levels, showed no significant correlation with confirmed case count increases. Random Forest Analysis assessed the influence of wind speed and AOD, showing relative importance of 0.31 and 0.23 on the daily increase percent of confirmed cases, respectively. This study may serve as a reference for better understanding and predicting factors affecting COVID-19 transmission and diffusion routes, focusing on the role of MED intrusions.
\end{abstract}

Keywords MED intrusion $\cdot$ Khuzestan $\cdot$ AOD $\cdot$ Atmospheric stability class $\cdot$ SARS-CoV-2 Atmospheric air pollution

\section{Introduction}

Natural pathways are the primary sources of airborne particles on Earth, including marine aerosols and dust from arid areas (Shahsavani et al. 2020; Solomon et al. 2007). Levels of atmospheric particulate matter (PM) exceeding air

Responsible Editor: Lotfi Aleya

Jong R. Kim

jong.kim@nu.edu.kz

1 Department of Civil and Environmental Engineering, Nazarbayev University, Nur-Sultan, Kazakhstan 010000

2 Department of Chemical Engineering, Masjed-Soleiman Branch, Islamic Azad University, Masjed-Soleiman, Iran

3 Department of Medicine, School of Medicine, Nazarbayev University, Nur-Sultan, Kazakhstan 010000

4 Environmental Centre, Lancaster University, Lancaster LA1 4YQ, UK

5 Chair of Hydrobiology and Fishery, Institute of Agricultural and Environmental Sciences, Estonian University of Life Sciences, Tartu, Estonia
6 Department of Evolutionary Biology, Ecology and Environmental Sciences, University of Barcelona, Barcelona, Spain

7 Atmospheric Science and Meteorological Research Centre, Tehran, Iran

8 Faculty of Natural Resources and Environment, Islamic Azad University, Science and Research Branch of Tehran, Tehran, Iran

9 St Anne's College, University of Oxford, Oxford OX2 6HS, UK

10 The Environment and Resource Efficiency Cluster (EREC), Nazarbayev University, Nur-Sultan, Kazakhstan 010000 
quality standards and health guidelines are transported from deserts to inhabited areas under certain weather conditions (Marsham et al. 2013; Shahsavani et al. 2020). For example, Shamal winds and cyclones cover the Middle East with dust clouds, leading to the deterioration of atmospheric conditions during the summer (Alizadeh-Choobari et al. 2016). PM levels during such Middle East Dust (MED) events can be very high in western Iran: in the city of Ahvaz, a level of $>9000 \mu \mathrm{g} / \mathrm{m}^{3}$ was recorded on $27^{\text {th }}$ January 2017, and $5338 \mu \mathrm{g} / \mathrm{m}^{3}$ on $3^{\text {rd }}$ June 2010; and at Sanandaj a $\mathrm{PM}_{10}$ level of $5616 \mu \mathrm{g} / \mathrm{m}^{3}$ was recorded on 5th July 2009 (Rashki et al. 2021; Salmabadi et al. 2020; Shahsavani et al. 2012). The primary sources of dust particles for these events were located in Northern Iraq and along the Iraq-Syria border. In this arid climate, the vulnerability level of wind erosion is increased due to reduced vegetation coverage and major soil disturbance linked to human activities such as conflicts and land-use dynamics (Modarres et al. 2017). Meteorological elements such as reductions in precipitation, low soil moisture level, high temperature, wind speed, and relative humidity (RH) intensify these MED events (Klingmüller et al. 2016).

Airborne particles are linked to long-term and shortterm impacts on human health, such as cardiopulmonary and respiratory diseases (Middleton 2020). The American Cancer Society recorded 8-18\% more cardiovascularrelated deaths due to an increase of $10.0 \mu \mathrm{g} / \mathrm{m}^{3}$ in $\mathrm{PM}_{2.5}$ for 552,000 participants over 16 years in from US metropolitan areas (Fromme et al. 2008; Goudarzi et al. 2018; Niu et al. 2010). It is worth noting that health conditions caused by natural PM (mineral dust) may differ from anthropogenic PM (Bart et al. 2011; WHO 2007). Some epidemiologists observed higher mortality rates on higher PM level dusty days than non-dusty days (Neophytou et al. 2013; Sandra et al. 2011).

In the Iranian cities of Ahvaz and Kermanshah, some studies have shown increases in respiratory hospitalizations and cardiorespiratory mortality during dust storms (Delangizan and Jafari Motlagh 2013; Geravandi et al. 2017). Ahvaz city in Khuzestan, which experiences major MED intrusions, experienced a $3.3 \%$ rise in daily deaths associated with a $10.0 \mu \mathrm{g} / \mathrm{m}^{3}$ increment of $\mathrm{PM}_{10}$ concentration during dusty days as compared to a $1.0 \%$ increase on nondusty days (Shahsavani et al. 2020). The authors found that any PM exposure during an MED intrusion may adversely impact human health in arid and downwind affected areas (receptors) (Shahsavani et al. 2020).

During atmospheric transport, pollutants may be integrated into dust clouds and reach areas (receptors) downwind. Local gaseous pollutants (e.g., $\mathrm{SO}_{2}$ ) can also condense on dust particles (Rodriguez et al. 2011). During dust episodes, the accumulation, transport, and condensation of pollutants could make dust more dangerous to human health. Dust storms can transport bioaerosols on a large scale and affect ecosystems and populations downwind. Dust and sandstorms are capable of introducing many foreign microorganisms into the global system. Microorganisms found in desert dust are typically very resilient and highly resistant to desiccation, temperature extremes, high salinity, and exposure to ultraviolet radiation (Behzad et al. 2018; Broomandi and Rashidi 2018; Gonzalez-Toril et al. 2020; Goudarzi et al. 2014; Kai et al. 2017; Neisi et al. 2019; Nourmoradi et al. 2015; Reche et al. 2018; Weil et al. 2017).

Particulate matter can provide a substrate, allowing a virus to maintain a long-term (hours or days) presence in the ambient atmosphere. Environmental parameters are the key players in viral inactivation. For example, high temperature and solar radiation may accelerate inactivation rates of viruses, while high humidity can promote diffusion rate (Setti et al. 2020; Després et al. 2012; Wigginton and Boehm 2020). Recent studies noted an association between ambient PM concentrations and presence of viruses among exposed populations (Chen et al. 2010).

In China, a positive correlation $(p<0.001)$ was found between childrens' infection rates of RSV (respiratory syncytial virus) with $\mathrm{PM}_{2.5}$ and $\mathrm{PM}_{10}$ concentration. RSV deeper penetration in the respiratory system is reportedly promoted by particle-based transport (Ye et al. 2016). Another investigation found a positive correlation between viral disease and exposure to high $\mathrm{PM}_{2.5}$ levels in China (Chen et al. 2017). Zhu et al. (2020) evaluated the association of short-term exposure to higher levels of air pollution with increases in risk of infection. The authors of this paper showed a substantial positive correlation between four days of exposure ( $23^{\text {rd }}$ January 2020 to $29^{\text {th }}$ February 2020) to concentrations of $\mathrm{PM}_{2.5}$ and $\mathrm{PM}_{10}$ and number of new daily positive cases in 120 cities in China. They also found that a $10.0 \mu \mathrm{g} / \mathrm{m}^{3}$ increase in $\mathrm{PM}_{2.5}$ and $\mathrm{PM}_{10}$ levels was positively correlated with a $1.76 \%$ (95\% CI: 0.89 to 2.63 ) and $2.24 \%$ (95\% CI: 1.02 to 3.46 ) rise in confirmed daily positive cases (Zhu et al. 2020). A study based in the USA found that longterm exposure to $\mathrm{PM}_{2.5}$ was positively correlated with increased mortality risk of COVID-19 (Wu et al. 2020). They reported that a $1.0 \mu \mathrm{g} / \mathrm{m}^{3}$ incremental increase of $\mathrm{PM}_{2.5}$ positively correlated with an increase in the SARSCoV-2 mortality rate of $8 \%$ (Wu et al. 2020).

In Istanbul, Turkey, a study of the associations of meteorological parameters and air quality with daily COVID-19 case numbers found that air quality indices, temperature, and relative humidity were associated with the spread of disease in the population (Shahzad et al. 2021). Temperature 
and $\mathrm{NO}_{2}$ concentrations were the primary factors associated with a substantial spike in the infection and death rates of COVID-19 in Istanbul. Moreover, they found a significant association for $\mathrm{PM}_{10}, \mathrm{PM}_{2.5}, \mathrm{O}_{3}$, and relative humidity with COVID-19 transmission (Shahzad et al. 2021).

A study conducted in the state of NJ, USA, explored correlations between meteorological parameters and new COVID19 case counts, finding that temperature was negatively correlated, and relative humidity and air quality index were positively correlated with new case counts. $\mathrm{PM}_{2.5}$, population density, human development index, and health security index were also correlated with spread of the disease (Doğan et al. 2020). Moreover, autoregressive distributed lag (ARDL) analysis showed that relative humidity, air quality, and infections had lagged effects with COVID-19 spread across New Jersey (Doğan et al. 2020).

Viruses such as SARS-CoV-1 are likely to spread in the air within the formation of tiny liquid droplets and then could freely transport with their viral content over tens of meters from their origin in the air (Hadei et al. 2020; Morawska and Cao 2020; Rahmani et al. 2020). Researchers have concluded that COVID-19 can spread person-to-person through the air (Bourouiba 2020; Domingo et al. 2020; Hadei et al. 2020; Jayaweera et al. 2020; Morawska and Cao 2020). Recently published studies suggested two mechanisms of direct and indirect aerosol transmission routes of SARS-CoV-2. With direct dispersion human-exhaled aerosols are transmitted in close proximity, while with indirect dispersion ambient particles act as cargo to spread the virus. Additionally, the presence of particulate matter can stimulate the expression of Transmembrane Serine Protease 2 (TMPRSS2) and AngiotensinConverting Enzyme 2 (ACE-2), causing an increase in the SARS-CoV-2 binding sites and the facilitation of infection efficiency (Cao et al. 2021; Li et al. 2020; Paital and Agrawal 2020; Yao et al. 2020a).

To the best of our knowledge, there is no study examining the association between MED dust storms and new case counts of SARS-CoV-2. This study aims to assess plausible links between MED dust intrusion and COVID-19 infection counts by assessing dust storm measures and disease occurence. This research is founded on the hypothesis of this possible relations in two ways: (1) the population becomes more susceptible to viral exposure during epidemics due to the damaging effect of MED events on the respiratory system, and (2) atmospheric clouds of dust can act as a carrier and increase atmospheric transportation of the virus (SARSCoV-2). During the pandemic, a MED dust storm occurred on April 25-26, 2020, in Khuzestan, Iran, with the number of new cases in several cities increased dramatically followingr the event. To confirm the given hypotheses, the relationship between AOD levels and daily percentage increase in positive cases of COVID-19 are statistically examined in detail in 20 cities in Khuzestan, Iran.

\section{Material and methods}

\section{Case study and meteorological characteristics}

Khuzestan province covers $63,213 \mathrm{~km}^{2}$ in southwestern Iran and is home to 4.7 million inhabitants. It is located between $31^{\circ} \mathrm{N}$ and $32^{\circ} \mathrm{N}$ latitudes and $48^{\circ} \mathrm{E}$ and $49.5^{\circ} \mathrm{E}$ longitudes (Fig. 1). The topographic altitudes change from 0 to $3740 \mathrm{~m}$. The weather ranges from humid to arid. While the southern regions experience a tropical climate, the northern regions have a colder climate. Summertime begins in April and lasts to September, and wintertime lasts from October to March. During summer, the annual mean maximum temperatures are close to $50{ }^{\circ} \mathrm{C}$, with the minimum value occurring in March (close to $9^{\circ} \mathrm{C}$ ). The annual precipitation levels range 995-1100 $\mathrm{mm}$ in the north and 150-256 $\mathrm{mm}$ in the south. Roughly $70 \%$ of annual rainfall is from February to April. The annual amount of evaporation is $2000-4000 \mathrm{~mm}$. The direction of the prevailing wind speed is from west to east and from northwest to southeast (Zarasvandi et al. 2011).

There are two main origins of dust storms in Khuzestan, including neighboring countries such as Iraq and Saudi Arabia (Mohammadpour et al. 2020; Salmabadi et al. 2020) and susceptible to land to wind erosion in the west of Khuzestan and desiccation of water bodies such as Karkheh river and Hourazim wetland (Malamiri et al. 2019; MalAmiri et al. 2022). According to the long-term analyses of meteorological-dust data, the highest levels of dusty days for both Iran and the Middle East occurred in the cities of Khuzestan province, Iran (Salmabadi et al. 2020), with a maximum

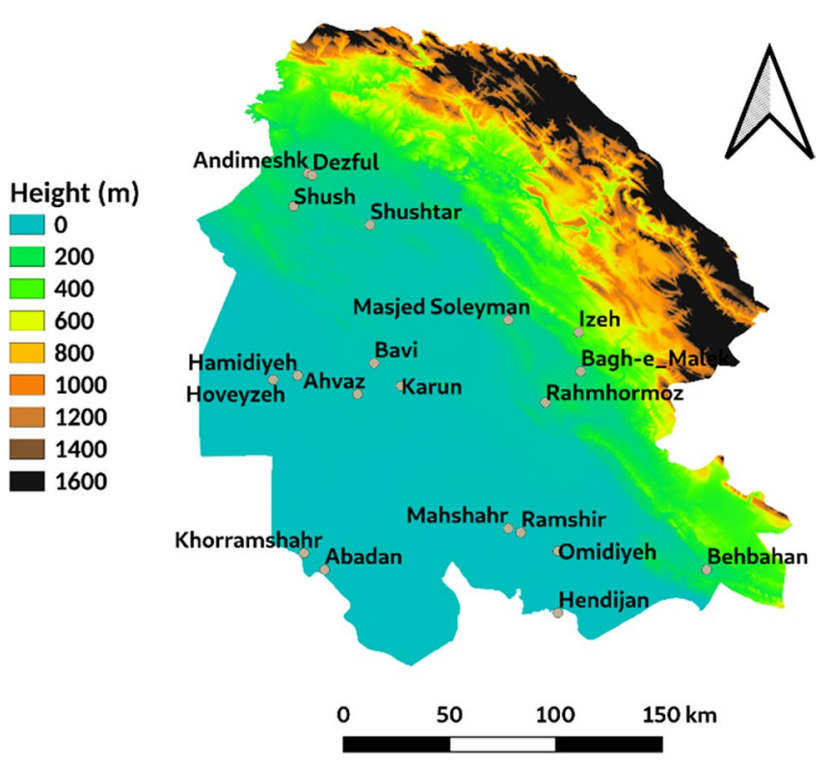

Fig. 1 Khuzestan province: digital elevation model and locations of the studied cities 
number of 322 dusty days in Ahvaz during 2011. The increase in the number of dusty days following 2008 was caused by the shifting to the extended dry conditions over the Fertile Crescent in Iraq (Klingmüller et al. 2016), and the continued spike of dust-AODs in downwind areas such as Khuzestan (Hamzeh et al. 2021a). Dusty days are more frequent in the late spring and summer, with dust storms having horizontal visibility below $100 \mathrm{~m}$ most common in June and July (Mohammadpour et al. 2020; Salmabadi et al. 2020). The number of dusty days also increased in February and March due to the frontal dust storms over the Iraqi plains, with the highest impact on the southwest of Iran (Gholamzade Ledari et al. 2020; Hamidi 2019; Hamzeh et al. 2021b).

\section{Dust episode identification, along with differentiation between dust storm contributions and contributions from other sources to PM levels}

Regional dust storms and other phenomena such as stable weather conditions and inversions can increase ambient PM levels. In our study, dusty days due to regional dust intrusions were statistically separated from non-dusty days by analyzing air pollutant levels. The threshold value of 100 $\mu \mathrm{g} / \mathrm{m}^{3}$ for $\mathrm{PM}_{10}$ concentration was applied to distinguish dusty days from regular non-dusty days, as utilized by other researchers (Escudero et al. 2007; Givehchi et al. 2013). Multi-pollutant behavior analyses were used to distinguish days influenced by either inversion/atmospheric conditions or regional dust storms. During dust intrusion, notable increases in the PM levels are expected with no noteworthy increment of gaseous pollutants' concentrations, mainly formed from primary combustion like Carbon Monoxide (CO). To separate episodic days, the duration of notably elevated concentration of $\mathrm{PM}_{10}$, i.e., the daily average concentration with at least one STD (standard deviation) above the mean value, was chosen. During the study, when the daily carbon monoxide concentrations were at least one STD below the mean, the day's measurements were included in the analysis, as applied by Givehchi et al. (2013). Among the determined dusty days in Khuzestan province, the dust storm outbreaks causing elevated $\mathrm{PM}_{10}$ concentrations (daily $\mathrm{PM}_{10}$ concentration above $200 \mu \mathrm{g} / \mathrm{m}^{3}$ ) were selected for includion in the study. A statistical procedure by Givehchi et al. (2013) was followed to separate the amount of $\mathrm{PM}_{10}$ increases caused by an intensive dust intrusion from local anthropogenic sources. Firstly, the initial correlation coefficients $\left(R^{2}\right.$ with $p$ values $\left.<0.0001\right)$ of hourly-based $\mathrm{PM}_{10}$ concentrations in the studied time frame among all pairs of available air quality stations were calculated during dust episodes. The pairs with a remarkably lower correlation coefficient $(<0.6)$ were excluded from the studied cities since it is expected that they would be primarily affected by local emission sources, even during the dust intrusion.

\section{Data collection}

In the current study, the hourly PM10 data were obtained from the National Air Quality Information System (Iranian meteorological organization). Also, the daily data of number of new cases and deaths were obtained from the database of the official coronavirus site enabled by the Ministry of Health (Food and Drug Association).

\section{Cross-correlation calculation among combined AOD and daily increase percent of COVID-19 infection}

Since cross-correlation helps to evaluate the similarity between two-time series, it was implemented to explore the relationship between combined AOD and the daily percentage increase of SARS-CoV-2 infection (Wang et al. 2019). In its application, one of the main limitations is the different distribution characteristics of data sets correlated. During the growth or spread period, the pandemic usually follows an increasing trend; however, the AOD data is more random with some short-term autocorrelations due to the nature of local emissions and dust incursion characteristics. To provide correct correlation results, it is necessary to eliminate the typical growth characteristics of the COVID cases. In this study, a transformation procedure was used to normalize the virus infection growth characteristics, which typically follows an exponential function, while log transformation or original data was sufficient to have a normal distribution for AOD data. The percentage of daily increase values COVID infection numbers were calculated regarding the preceding day only (e.g., $=\frac{\operatorname{COVID}_{t}-C^{-} O V I D_{t-1}}{\operatorname{COVID}_{t-1}}$, where $\mathrm{COVID}_{t}$ is the number of new cases in a day, and $\mathrm{COVID}_{t-1}$ is the number of new cases in a preceding day).

The positive lags denote correlations among the AOD at time $t$ with the increasing percentage of COVID-19 at time $t+1, t+2$. The lag with the highest correlation coefficient was identified when the combined AOD and daily percentage increase of COVID-19 infection match the best.

COVID-19 infection data were received from the Iranian Ministry of Health and Medical Education. Cross-correlations between the daily combined AOD and the increase in the percentage of COVID-19 infection numbers were calculated for 20 cities in the province starting from $20^{\text {th }}$ April 2020 to $5^{\text {th }}$ May 2020. Before $20^{\text {th }}$ April, the infection data were not reported for each city, so it was impossible to include the data of earlier pandemic periods. The studied cities are listed in Table S1 in the supplementary material. 


\section{Grouping the studied cities using the K-means clustering method}

To investigate the possible association between weather conditions and vulnerability to infection during dusty days, it was decided to assign each city into a cluster using the K-means clustering method. A dataset $D=\left\{O_{1}, O_{2}, \ldots, O_{n}\right\}$ has $n$ objects (instances) each $O_{i}$ is an object as a p-dimensional explanatory variable in the dataset (e.g., Pasquil Stability Class (PSC), Planetary Boundary Layer Height (PBLH), Wind speed, AOD, Duration of MED, and Population Density). The studied domain needs division into a combination of $k$ clusters, representing a vector $C K M=\left\{C_{1}, C_{2}, \ldots, C_{k}\right\}$ with denoted centroids by $\mu=\left\{m_{1}, m_{2}, \ldots, m_{k}\right\}$. The beginning step is the randomly assigning of $k$ points as cluster centers. For each data point, $O_{i}$ is a distance to each cluster centroid $m_{j}$ and was calculated through one distance metric like Manhattan, Euclidean, Minkowski, or Chebyshev distance. The argminj dist $\left(O_{i} m_{j}\right)$ is used to figure the nearest cluster for the respective instance to be assigned. The new midpoint of clusters is calculated by $m_{j}=\left(\frac{1}{n_{j}}\right) \sum_{O_{j} \in m_{j}} O_{j}$, where $n_{j}, m_{j}$, and $O_{i}$ the number of objects in cluster $j$, the centroid of cluster $j$, and the dataset instances, respectively. Iteratively, this process proceeds to where no data point alters cluster membership (Grace et al. 2016; Tüysüzoğlu et al. 2019).

\section{Statistical analysis}

Random Forest Analysis (RFA) was used in the current study to evaluate the relative importance of parameters including (AOD, temperature, PBLH, surface pressure, relative humidity, and wind speed) affecting the daily increase percent of COVID-19 infection. RFA helped in the selection of the most critical predictors affecting the response based on a classification from zero (no importance) to one (highest importance) (Molinaro et al. 2011).

\section{MODIS $10 \mathrm{~km}$ AOD products}

Deep blue AOD (Aerosol Optical Depth) data from the Aqua-MODIS $550 \mathrm{~nm}$ Collection 6 MODIS and TerraMODIS $550 \mathrm{~nm}$ Collection 6 MODIS were employed to investigate the changes in daily PM levels in the atmospheric column over 20 cities. At a $10-\mathrm{km}$ resolution, the standard MODIS Level 2 (L2) AOD products are distributed. MYD04_L2 data from the Aqua-MODIS $550 \mathrm{~nm}$ L2 Aerosol Products and MOD04_L2 data from TerraMODIS $550 \mathrm{~nm}$ L2 Aerosol Products for the study duration were extracted from LAADS (MODIS L1 Level 1
Atmosphere Archive and Distribution System) (http:// ladsweb.nascom.nasa.gov/).

\section{AOD combination from Terra and Aqua}

For improving the AOD spatial coverage in our study, DB_ DT AOD from Terra and Aqua (MODIS-carrying satellites) were combined by averaging. The method of averaging the Aqua and Terra measurements successfully estimates the daily AOD average mentioned in other studies (Lee et al. 2011; Nabavi et al. 2018). When either Aqua or Terra is missing, AOD with the help of simple linear regression can be estimated (Eqs. (1) and (2)) among daily Aqua and Terra AOD values (Hu et al. 2013; Nabavi et al. 2018).

$D B \_D T A O D_{\text {ave }}=\frac{\left(\hat{\tau}_{\text {Terra }}+\tau_{\text {Aqua }}\right)}{2}$, if Terra is missing

$D B \_D T A O D D_{\text {ave }}=\frac{\left(\tau_{\text {Terra }}+\hat{\tau}_{\text {Aqua }}\right)}{2}$, if Aqua is missing

$D B \_D T A O D_{\text {ave }}=\frac{\left(\tau_{\text {Terra }}+\tau_{\text {Aqua }}\right)}{2}$, if both are available

$\hat{\tau}_{\text {Terra }}=0.816 \times \tau_{\text {Aqua }}+0.0652$

$\hat{\tau}_{\text {Aqua }}=0.7428 \times \tau_{\text {Terra }}+0.0725$

$\hat{\tau}$ and $\tau$ are estimated and available DB_DT AOD, respectively.

\section{Reanalysis for weather monitoring}

ERA5 reanalysis data, produced by $\mathrm{C} 3 \mathrm{~S}$ at ECMWF, as the current atmospheric reanalysis and regard to the 2016 version of IFS (Integrated Forecasting System), was employed to investigate the probable impact of meteorological data (including daily mean surface pressure $(\mathrm{KPa})$, daily mean wind speed $(\mathrm{m} / \mathrm{s})$, daily mean relative humidity $(\%)$, daily mean temperature $\left({ }^{\circ} \mathrm{C}\right)$, daily mean planetary boundary layer height (m)) on the increment of SARS-CoV-2 infection in Khuzestan province, Iran.

\section{Investigation of atmospheric stability class}

Stability time series by covering before-during-after dust intrusion for the studied cities, including Pasquil stability class (PSC) and vertical mixing Planetary Boundary Layer Height (PBLH), were downloaded from https://www.ready. noaa.gov/READYamet.php and were studied for any significant commonalities or differences between cities based on the dust incursion times, respectively.

\section{Monitoring dust storm events over Khuzestan using the Visible/IR images of SEVIRI}

The Visible/IR images from Spinning Enhanced Visible and Infrared Imager (SEVIRI), carried by MSG (Meteosat 
Second Generation) satellites, are employed in our study to investigate dust storms. For continuous dust monitoring, the EUMETSAT (European Organisation for the Exploitation of Meteorological Satellites) recommends RGB images (available free of charge every hour: http://www.eumetsat. int/Home/Main/Image_Gallery/Real_Time_Imagery/index. $\mathrm{htm})$. The infrared channel data from SEVIRI is based on RGB image compositions, where dusty pixels show up in pink colors, and is used to monitor the dust event evolution during both day and night in deserts (Martínez et al. 2009).

\section{HYSPLIT model}

For analyzing the sources and trajectories of dust particles, the Online HYSPLIT version 4 (Hybrid Single Lagrangian Integrated Trajectory) model was employed with $1^{\circ} \times 1^{\circ}$ resolution meteorological data (Draxler and Hess 1997). An HYSPLIT ensemble trajectory calculates the multiple pathways from one position by all-feasible deviations in X, $\mathrm{Y}$, and Z. For the reduction of the model uncertainty, ensemble trajectories are used to compute all possible pathways (Draxler and Hess 1997).

\section{Results and discussion}

\section{Identification of a regional dust invasion event during the pandemic growth period}

In Khuzestan, several air quality stations record hourly $\mathrm{PM}_{10}$ concentrations. The recorded data from Ahvaz, Shush, Shushtar, Ramshir, Hamidiyeh, Abadan, Hendijan, Andimeshk, Dezful, and Omidiyeh were considered. Others were excluded due to the limited data coverage and unreliability with several hourly/daily gaps during the studied period ( $1^{\text {st }}$ April $2020-30^{\text {th }}$ April 2020). The resulting numbers of dusty days were 2, 2, 1, 1, 5, 4, 1, 1, and 3 for Shush, Ahvaz, Shushtar, Ramshir, Hamidiyeh, Abadan, Hendijan, Andimeshk, Dezful, and Omidiyeh, respectively during April 2020. Among the determined dusty days, one dust episode outbreak on $25^{\text {th }}-26^{\text {th }}$ April 2020, causing the elevated levels of $\mathrm{PM}_{10}$ (daily $\mathrm{PM}_{10}$ concentration above 200 $\mu \mathrm{g} / \mathrm{m}^{3}$ ), occurred and was selected for our research. To distinguish the increases of $\mathrm{PM}_{10}$ caused by dust intrusion from local anthropogenic sources, the initial correlation coefficient ( $R^{2}$ with $p$ values less than 0.0001 ) of hourly $\mathrm{PM}_{10}$ concentration among all pairs of air quality stations during dust outbreak was calculated. Correlation values above 0.75 showed that any of the studied stations were influenced by local sources during dust intrusion, and the amount of $\mathrm{PM}_{10}$ increases during dust outbreak was caused by the dust intrusion. Fig. 2 illustrates the time series of daily measured $\mathrm{PM}_{10}$ concentration and combined daily extracted deep blue AOD over the mentioned cities above.

Globally, the AErosol RObotic NETwork project (AERONET) provides distributed observations of spectral aerosol optical depth (AOD), precipitable water in diverse aerosol regimes, and inversion products (https://aeronet.gsfc.nasa. gov/). $\mathrm{PM}_{10}$ data (9 cities out of 20 cities), the correlation among the combined AOD data, and ground-based $\mathrm{PM}_{10}$ measurements were acceptable with the $R$ values ranging from 0.60 to 0.78 (all $p$ values $<0.0001$ ) (details of regression results presented in Supplementary Material). Both series in Fig. 2 represent a peak in $\mathrm{PM}_{10}$ and AOD values during dust intrusion on $26^{\text {th }}$ April 2020.

To monitor MED outbreaks over land, their migration, and the corresponding changes in $\mathrm{PM}_{10}$ levels in Khuzestan province, HYSPLIT backward trajectory modeling and the Visible/IR images of SEVIRI with a temporal resolution of $60 \mathrm{~min}$ and spatial resolution of $3 \mathrm{~km} \times 3 \mathrm{~km}$ were implemented in our study (Figs. 3 and 4). Transport pathways of dust particles were tracked through 6-h time intervals up to $24 \mathrm{~h}$ before dust episodes reaching the study locations using HYSPLIT backward trajectories on $25^{\text {th }}$ April 2020. Fig. 3 shows the main corridors of dust transport originating from arid and semi-arid areas in northern Saudi Arabia and central parts of Iraq to Iran's west and southwest regions.

The Visible/IR images of SEVIRI are employed to support HYSPLIT results and identify dust storms (Fig. 4) that were consistent with the spatial and temporal coverage. In the thermal infrared part of the electromagnetic spectrum (8.7 to $12.0 \mu \mathrm{m}$ ), atmospheric dust can create a cooling anomaly in 'clear-sky' conditions (Hennen et al. 2019). Relative RGB (Red/Green/Blue) beam strengths are rendered from inter-channel Brightness Temperature Differences (BTD), configured with specific limits (cf. Table 1 in Hennen et al. 2019) to distinguish 'thermally insulating' atmospheric components (such as soot and clouds from biomass burning) from atmospheric dust (Brindley et al. 2012; Hennen et al. 2019). In the 'Dust RGB' product, meteorological clouds appear as red or brown, the dust appears magenta or pink, and bare surfaces appear as white or blue (Fig. 3) (Brindley et al. 2012; Hennen et al. 2019). According to Fig. 4, dust storms originated in central parts of Iraq and northern Saudi Arabia, gradually moved to the west and southwest of Iran, including Khuzestan province. Along with the results of applied statistical analyses to the pollutant concentrations, both HYSPLIT backward trajectory modeling and the Visible/IR images of SEVIRI confirmed that a dust storm started on $25^{\text {th }}$ and peaked on $26^{\text {th }}$ April 2020, similar to a prior case that covered large areas of Iraq and northern regions of Saudi Arabia that afterwards reached Khuzestan (Ashrafi et al. 2014; Martínez et al. 2009).

Previous studies have shown two different dust storm corridors to Khuzestan province in Iran: (a) W-E direction, from 
Fig. 2 The time series of (A) combined daily extracted deep blue AOD, and (B) measured daily $\mathrm{PM}_{10}$ concentration and in Khuzestan, Iran during $1^{\text {st }}$ April 2020 to $30^{\text {th }}$ April 2020
A
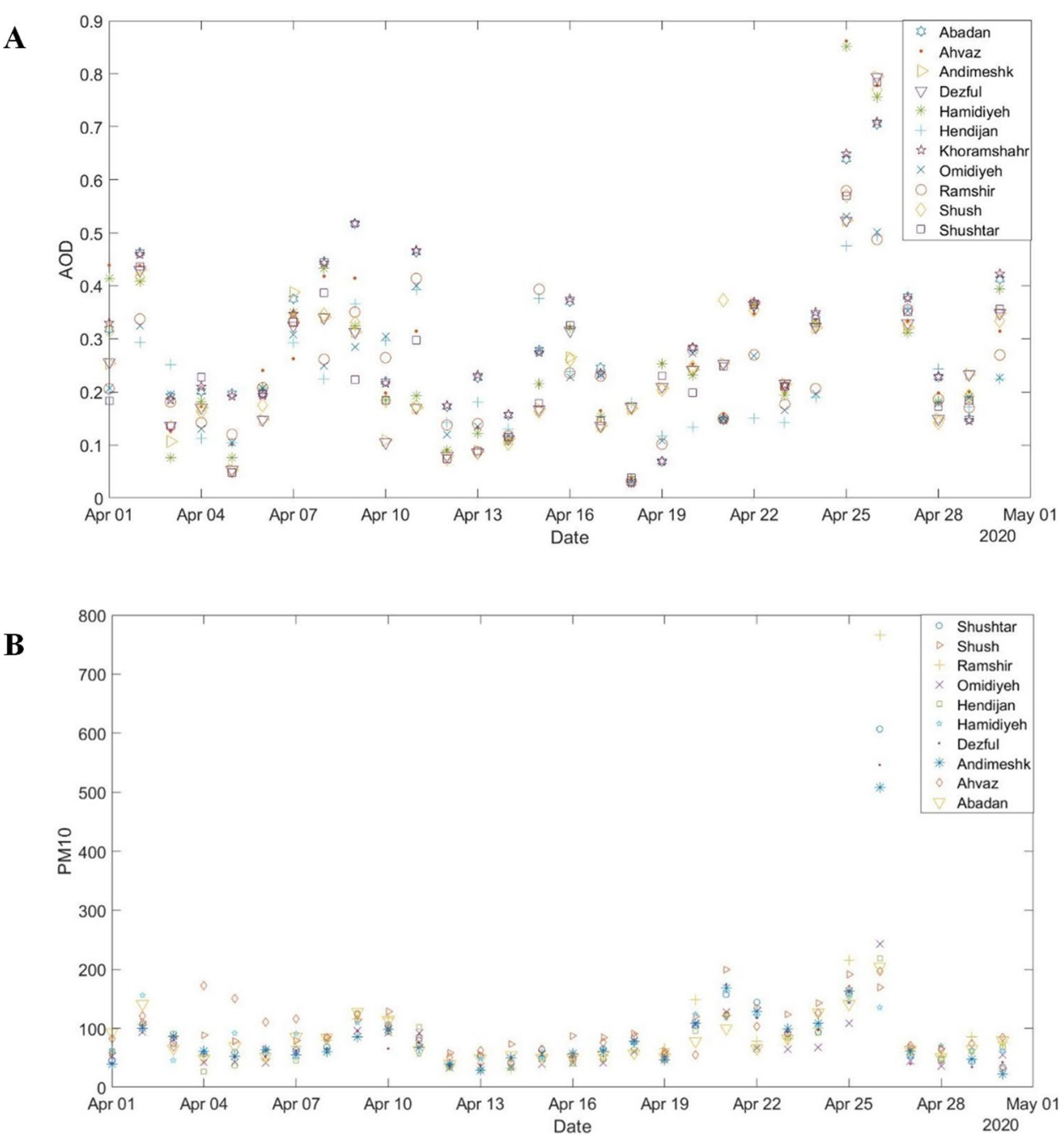

central regions of Iraq to the southwest and west of Iran, and (b) NW-SE direction, from eastern Syria and northwestern Iraq (Baghbanan et al. 2020; Broomandi and Bakhtiar Pour 2017; Cao et al. 2015; Zarasvandi et al. 2011). During warm periods from March to September, Shamal winds are responsible for dust transportation from eastern Syria, western regions of Iraq, and Jordan to Khuzestan province. The main dust events over Iran come from the semi-arid and arid region of the dust belt, mainly northern, eastern, and central parts of Syria and Iraq, and the northern part of Saudi Arabia (Aliabadi et al. 2015; Broomandi and Bakhtiar Pour 2017; Cao et al. 2015).

\section{The trend of changes in the COVID-19 situation in Khuzestan, Iran}

The first confirmed COVID-19 case was reported in Iran in mid-February 2020. As a result, lockdown and precautionary measures were implemented from $21^{\text {st }}$ March to $21^{\text {st }}$ April in 2020 in the whole country. By the beginning of June 2020, the total number of infected, dead, and recovered people in Iran are 157,562, 7942, and 123,077, respectively, while in Khuzestan are 15,988, 595, and 14,591, respectively. It is worth mentioning that the Khuzestan population ratio to Iran is about $5.9 \%$. However, the rates of total infected, death, and recovered people in this city are around $10 \%, 7.5 \%$, and $12 \%$.

According to Fig. 5, the initial number of Khuzestan cases had been slightly increasing, while the numbers were rapidly decreasing in the whole country. Subsequently, however, case numbers massively increased in Khuzestan, while the numbers were decreasing in the country, to the extent that the increase rate in Khuzestan outstripped that of the country starting from $27^{\text {th }}$ April 2020. The infection ratio of new cases in the province to the country was $9.6 \%, 13.2 \%$, $15.0 \%, 19.0 \%$, and $28.0 \%$ on $25^{\text {th }}$ April (the day of the end of the studied dust storm event), $27^{\text {th }}$ April (2 days after the dust intrusion), 29 ${ }^{\text {th }}$ April (4 days after the dust intrusion), $30^{\text {th }}$ April (5 days after the dust intrusion), and $2^{\text {nd }}$ May (7 days after the dust intrusion), respectively. Right after a 7-day lag, the newly reported number of cases tripled in 
Fig. 3 HYSPLIT Back trajectory simulation for (A) Abadan, (B) Ahvaz, (C) Dezful, and (D) Mahshahr cities in Khuzestan province, Iran on $26^{\text {th }}$ April 2020
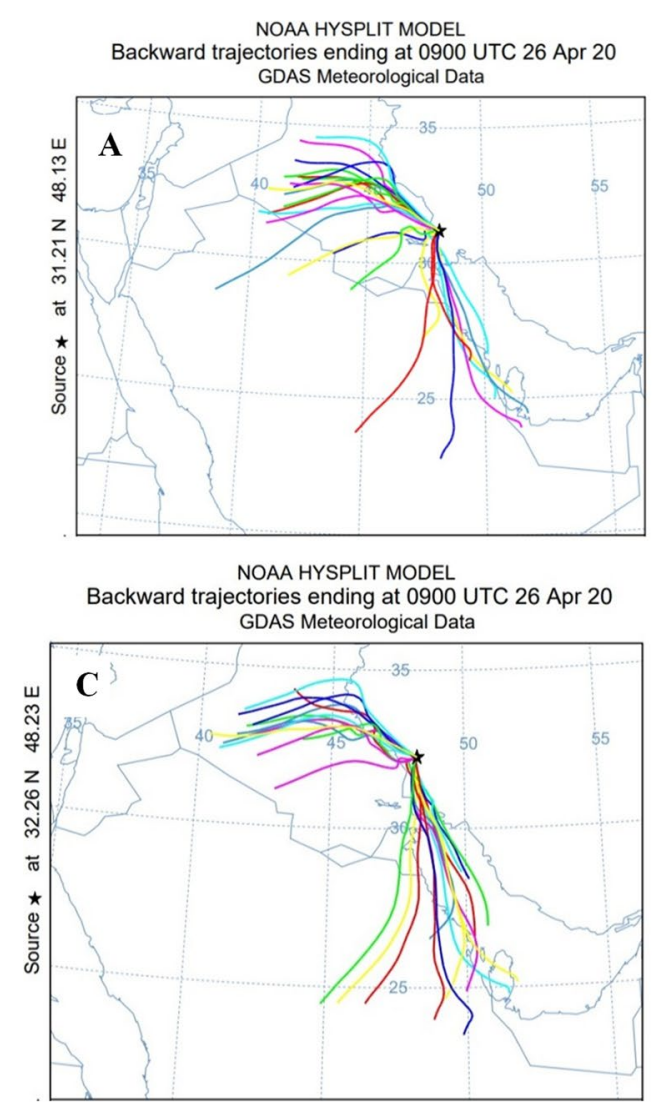

this province, indicating a significant abnormal increase in the daily infection rate. Additionally, Fig. 5 shows a slight increase in the overall death rate in Iran, while there is a rapid increase in death rate in Khuzestan.

\section{Influences of climate parameters on aerosol optical depth (AOD) in Khuzestan, Iran}

Meteorological variables such as temperature, planetary boundary layer height (PBLH), surface pressure, $\mathrm{RH}$ (relative humidity), wind speed, and direction could impact the formation and dispersion of dust storms (Miri et al. 2017; Pirsaheb et al. 2016). The Pearson correlation coefficients analyses show that daily combined AOD in studied cities of Khuzestan, Iran had a statistically significant positive correlation with daily average wind speed $\left(R^{2}=0.40, p\right.$ value $<0.05)$, temperature $\left(R^{2}=0.32, p\right.$ value $\left.<0.05\right)$, PBLH $\left(R^{2}=0.13, p\right.$ value $<0.05$ (. However, no statistically significant correlation was observed among daily combined AOD and relative humidity and surface pressure. The elevated AOD levels can be due to the (a) any increase in air temperature; leading to a reduction in air humidity and increase in dust acceptance in air, (b) any decrease in relative humidity; preventing the precipitation phenomena and the act of washing and dust descending, (c) any increase in the wind speed; facilitating the transmission of dust particles from origins to downwind areas, (d) any reduction in surface pressure; lowering the chance of precipitation, air turbulence, and dust movement, (e) and any increase in PBLH; causing effective dispersion of dust particles in the vertical direction (Ashrafi et al. 2014; Guan et al. 2017; Namdari et al. 2018; Pirsaheb et al. 2016; Rashki et al. 2015; Zhu et al. 2018).

\section{Clustering of the cities according to atmospheric stability characteristics}

The relationship between virus spread and atmospheric dust is not straightforward, and possible latent relations with other independent factors, meteorological factors, and atmospheric stability characteristics should be considered. To find any significant commonalities or differences among the cities during the dust incursion times $\left(1^{\text {st }}\right.$ April 2020-30 ${ }^{\text {th }}$ April 2020), atmospheric stability data time series (e.g., Pasquil Stability Class (PSC) and Planetary Boundary Layer Height (PBLH)) studied for before, during, and after dust intrusion periods. Table 1 illustrates the dust event's duration, the dust cloud arrival time, PSC, PBLH, Wind Speed, AOD, and Population Density. The highest PBLH value was observed in Andimeshk (2526 m) with a stability class of B (Moderately unstable conditions), while in Mahshahr, the lowest value of $216 \mathrm{~m}$ occurred with a stability 
Fig. 4 SEVIRI satellite images for April dust storm. (A) $25^{\text {th }}$ April 2020 at 1:00 am, (B) $25^{\text {th }}$ April 2020 at 10:00 am, (C) $25^{\text {th }}$ April 2020 at 3:00 pm, (D) $25^{\text {th }}$ April 2020 at 7:00 pm, (E) $25^{\text {th }}$ April 2020 at 10:00 pm, and (F) $26^{\text {th }}$ April 2020 at 8:00 am

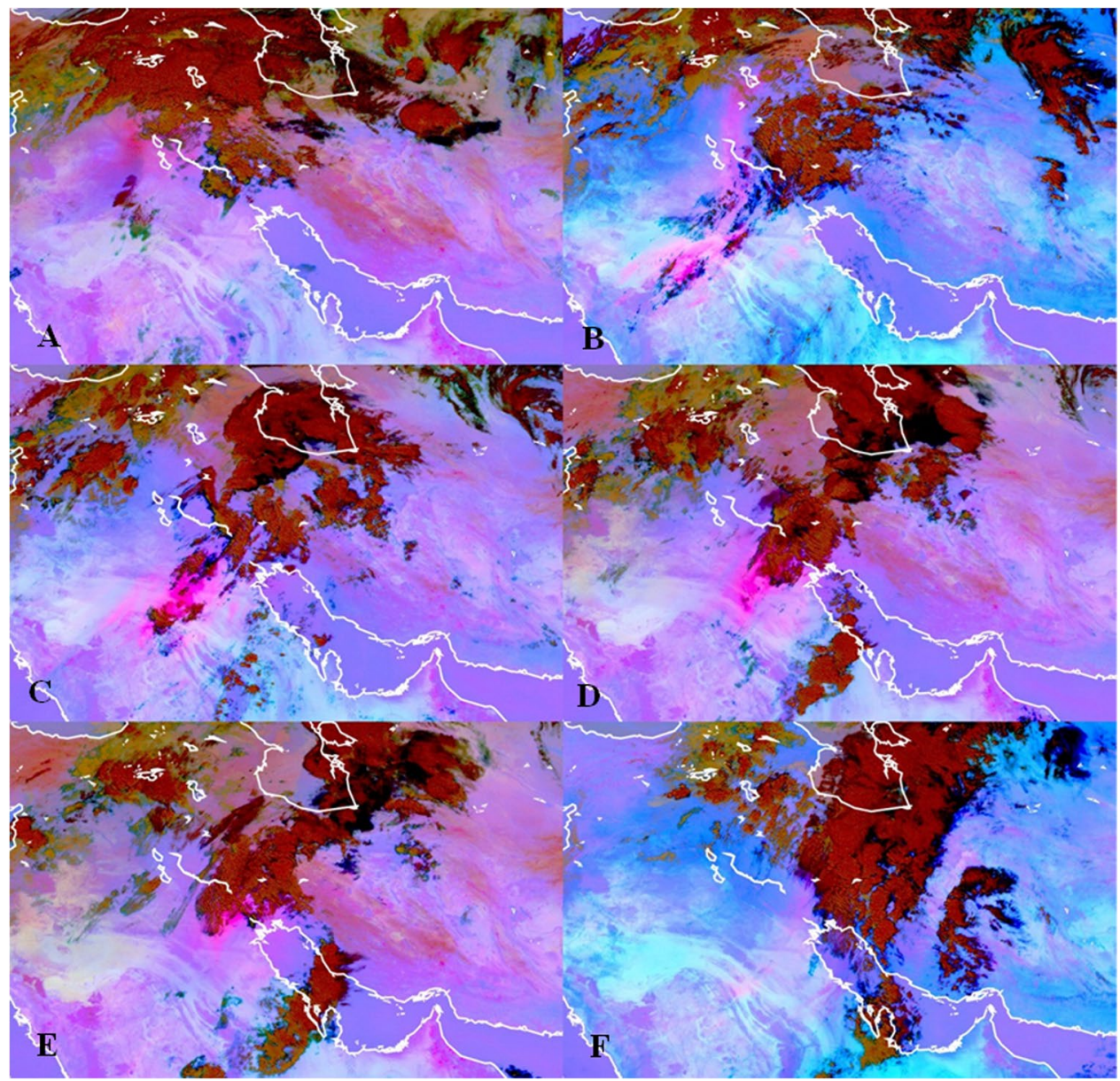

class of D (Neutral conditions) on $26^{\text {th }}$ and $25^{\text {th }}$ April 2020, respectively.

The K-means clustering algorithm clustered the cities to characterize their features or attributes (Shafiee et al. 2016a, b; Shobha and Asha 2017), and it measures different aspects of the cities' atmospheric stability characteristics. The clusters were extracted by considering attribute values of PSC, PBLH, AOD, wind speed, population density, and the duration of dust events. Table 2 summarizes the cluster analysis in Khuzestan, Iran. RFA analysis showed the critical role of wind speed and AOD with the relative importance of 0.31 and 0.23 , respectively, influencing the daily increase percent of COVID-19 infection (Table 3).

The cities were divided into three clusters based on their similarities. Cluster 1 includes Hendijan, Mahshar, Ramshir, Omidiyeh, and Behbahan cities with PBLH values below $1000 \mathrm{~m}$ (excluding Behbahan) with the stability classes of $\mathrm{C}$ and $\mathrm{D}$ and AOD ranging of $0.50-0.58$. In cluster 1 , the wind speed was relatively higher than the other two clusters (above $8.0 \mathrm{~m} / \mathrm{s}$ ). Cluster 2 includes Ahvaz, Shushtar, Abadan, Karun, Bavi, Andimeshk, and Shush cities with PBLH values above $2000 \mathrm{~m}$ (excluding Abadan), stability classes of $\mathrm{A}$ and $\mathrm{B}$, and AOD ranging of $0.60-0.86$. In cluster 2, the wind speed varied between 5 and $9 \mathrm{~m} / \mathrm{s}$. Cluster 3 includes Rahmhormoz, Khoramshahr, Dezful, Izeh, Baghe Malek, Masjed Soleyman, Hoveyzeh, and Hamidiyeh with PBLH values below $1000 \mathrm{~m}$, with stability class of C and D, and AOD ranging of $0.71-0.87$. In cluster 3 , the wind speed was relatively lower than others, varying between 1.0 and $8.0 \mathrm{~m} / \mathrm{s}$. The main differences in the observed relationships of the virus spread and the dust event for each city type are discussed in the following sections.

\section{Cross-correlation analysis between the combined $A O D$ data and the daily percentage increase of COVID-19 infection}

The SARS-CoV-2 virus has an incubation time ranging 2-14 days (Guan et al. 2020; Lauer et al. 2020); thus, any possible impacts of the infection spread following a dust event would be observed after several days. Cross-correlation is a method to evaluate two-time series if one is more correlated to a lagged measure of the other, helping to identify at which lag time the two-time series are most strongly correlated. In this study, several cross-correlations up to +10 days lag were applied to the studied cities. Due to a lack of 
Table 1 Atmospheric stability classification, time of arrival and duration of dust event, and combined extracted AOD values in Khuzestan province, Iran during the studied period $\left(1^{\text {st }}\right.$ April 2020-30 ${ }^{\text {th }}$ April 2020)

\begin{tabular}{llllllll}
\hline City & AOD & $\begin{array}{l}\text { Time of arrival on } \\
\text { 26 } \\
\text { th April 2020 } \\
\text { (UTC) }\end{array}$ & Duration & PSC & PBLH & Wind speed & Pop-density \\
& & & & & & \\
\hline Khoramshahr & 0.71 & $05: 30: 00$ & 10 & D & 897.6 & 6.17 & 74.4 \\
Shushtar & 0.78 & $08: 30: 00$ & 9 & B & 2072 & 7.77 & 78.93 \\
Andimeshk & 0.79 & $13: 30: 00$ & 2 & B & 2526 & 4.58 & 55.01 \\
Ahvaz & 0.86 & $09: 30: 00$ & 7 & B & 2083 & 6.44 & 267.8 \\
Abadan & 0.71 & $09: 30: 00$ & 7 & A & 1684 & 8.74 & 117.45 \\
Hamidiyeh & 0.85 & $07: 30: 00$ & 5 & C & 753.7 & 2.51 & 69.46 \\
Dezful & 0.79 & $05: 30: 00$ & 10 & D & 919.9 & 6.59 & 95.56 \\
Ramshir & 0.58 & $06: 30: 00$ & 9 & D & 569.2 & 12.24 & 33.34 \\
Omidiyeh & 0.53 & $09: 30: 00^{*}$ & 9 & C & 904.1 & 11.85 & 42.99 \\
Mahshahr & 0.50 & $21: 30: 00^{*}$ & 15 & D & 216 & 7.58 & 155.28 \\
Hendijan & 0.50 & $11: 30: 00$ & 5 & D & 391.9 & 5.45 & 10.25 \\
Shush & 0.77 & $12: 30: 00$ & 3 & B & 2485 & 6.80 & 56.67 \\
Masjed Soleyman & 0.83 & $06: 30: 00^{*}$ & 5 & D & 1080 & 3.85 & 52.12 \\
Izeh & 0.72 & $15: 30: 00$ & 15 & C & 731 & 1.09 & 52.49 \\
Behbahan & 0.56 & $09: 30: 00^{*}$ & 9 & C & 1753 & 8.12 & 62.62 \\
Bagh-e Malek & 0.81 & $15: 30: 00$ & 15 & C & 516 & 1.06 & 46.65 \\
Bavi & 0.86 & $09: 30: 00$ & 7 & B & 1993 & 9.13 & 70.07 \\
Karun & 0.60 & $09: 30: 00$ & 7 & B & 2298 & 7.78 & 88.45 \\
Rahmhormoz & 0.81 & $03: 30: 00$ & 15 & D & 317 & 7.72 & 62.58 \\
Hoveyzeh & 0.87 & $06: 30: 00$ & 5 & D & 1009 & 3.34 & 14.1 \\
\hline
\end{tabular}

* Occurred on $25^{\text {th }}$ April 2020 (UTC) data availability, analysis with a higher lag level, e.g., 14 days or more, was impossible. The event data sets consist of measurments for (1) the prior week before the event, (2) during the event (1-3 days), and (3) after the event, including all possible recorded days during the study period.

In Table 4, cities were categorized into four groups, based on calculated cross-correlations among the daily combined AOD and increases of COVID-19 infection numbers (\%) from 20/04/2020 to 09/05/2020. In group 1, cities of Masjed Soleyman, Khoramshahr, and Izeh with $R$ values above 0.70 showed that dust incursions might have a significant impact on the spread of COVID cases in these cities since the peak correlations come around 10-day lag that is the typical incubation period (Bontempi 2020). Group 2 includes Shushtar, Behbahan, Andimeshk, Abadan, Bagh-e Malek, Hamidiyeh, Ahvaz, Bavi, Dezful, and Ramshir, showing $R$ values ranging from 0.40 to 0.68 . In this group, the AOD levels are high (except Behbahan city with relatively high correlations). The peak correlations were observed around 4-5 days lag times, which might be related to the weakening of the infected persons' respiratory and immune systems (Bontempi 2020). Group 3 includes Omidiyeh, Mahshahr, Hendijan, and Karun, with $R$ values ranging from 0.31 to 0.43 . Most of the AOD levels in this group were lower, so they were utilized as our control group cities. These cities, having lower correlations for dust intrusions with new case counts, expectedly show no significant association with any lag. Finally, in group 4, the cities of Rahmhormoz, Hoveyzeh, and Shush, with $R$ values ranging from 0.23 to 0.34 , exceptions to the hypothesis since they had a higher level of dust incursion, but no significant correlation with no identifiable confirmed COVID case count increases.

In reference to Fig. 1 and Table 2, neighboring cities such as Bavi, Karun, and Shushtar had similar lag values. Correspondingly, the cities clustered together (Table 2) based on atmospheric stability and dust storm characteristics (e.g. Ahvaz, Shushtar, Andimeshk, and Abadan in Cluster 2 and Ramshir, Hendijan, Mahshahr, and Omidiyeh Hendijan in Cluster 1) fell into the same groups in Table 4. The cities of Cluster 3 (Rahmhormoz \& Hoveyzeh and Masjed Soleyman \& Khoramshahr \& Izeh) belonged to Groups $1 \& 4$. The reason behind this different grouping (based on crosscorrelation among combined AOD and daily increase percent of COVID-19 infection) might be due to poor medical surveillance such as insufficient testing in Shush, Rahmhormoz, and Hoveyzeh (grouped in G.4). Despite the similar atmospheric stability and dust storm characteristics, they were exceptions to the hypothesis, not showing a significant correlation.

Another notable exception was observed in Cluster 3. Khorramshahr (grouped in G.1) and Dezful \& Bagh-e Malek \& Hamidiyeh (grouped in G.2) were clustered together 
because they shared similar cross-correlation values. All cities in cluster 3 share similar atmospheric stability and dust storm properties, while they have different elevations. Khorramshahr is located near the sea and at a lower elevation, about $3 \mathrm{~m}$ above sea level. It is speculated that it was more vulnerable to the dust storm intrusion than Dezful, Bagh-e Malek, and Hamidiyeh, located farther inland, at $921 \mathrm{~m}, 734$ $\mathrm{m}$, and $52 \mathrm{~m}$ above sea level, respectively, even though their AOD levels were slightly higher than Khoramshahr.

\section{Study implications and limitations}

There is sparse research concerning COVID-19 epidemic phenomena and their possible association with PM levels and diffusion. Recently, studies showed a meaningful linkage among Saharan dust intrusion and observed COVID-19 outbreak in early 2020 on the Canary Islands, Spain, found that higher levels of $\mathrm{PM}_{2.5}$ caused by Saharan dust intrusions and air temperature inversions can boost severe COVID-19 outbreaks (Rohrer et al. 2020). Another study conducted in Spain, which examined the impact of Saharan dust intrusions on the incidence and severity of COVID-19, found that dust intrusion had an additional influence on COVID-19 incidences and hospital admission rates (Linares et al. 2021).

Desert dust events can increase the levels of ambient particulate matter $\left(\mathrm{PM}_{2.5}\right)$ as well as being a vector for fungal illnesses, which can intensify the mortality and morbidity related to SARS-CoV-2 (Verweij et al. 2020). The overburdening of hospitals and health services may also be linked to $\mathrm{PM}_{2.5}$ peak levels and particular meteorological conditions favorable for spreading and enhancing the virulence of COVID-19 (Rohrer et al. 2020). Additionally, the observed pattern of COVID-19 cases concentrated in the 30-50N latitude area suggests that dust carrying the virus may have been spread by a circum-global northern sub-tropical jet-stream in the high-altitude troposphere over northern parts of China in early Spring, 2020 (Wickramasinghe et al. 2020).

The authors speculated that dust particles responsible for carrying the COVID-19 virus were transported from considerable virus sources generated in Wuhan, China, toward southern parts of the USA, consequently across the Atlantic to Portugal and further states to the east (Wickramasinghe et al. 2020). Their study suggested that the primary deposition of the dust particles carrying the virus depends on the interaction between the jet-stream and regional meteorological systems, leading to COVID-19 outbreaks in different countries along this latitude belt (Wickramasinghe et al. 2020). The case of Brazil, which exceptionally is outside the 30-50N latitude belt, was suggested to being caused by the Azores cyclonic system affecting part of the jet-stream west of Portugal into the south-westerly trade winds with these winds entering Brazil in Spring 2020 (Wickramasinghe et al.
2020). It is recommended not only to monitor the prevalence of the virus in the future but also to consider the occurrence of meteorological conditions that can cause unexpected and uncontrollable SARS-CoV-2 outbreaks.

Some other researchers suggested that transmission of infectious diseases can occur rapidly with increased air pollution levels (Bontempi 2020; Chen et al. 2010; Peng et al. 2020; Wu et al. 2020; Yang et al. 2020; Ye et al. 2016; Zhu et al. 2020). Yang et al. (2020) discussed the susceptibility of people to viral disease due to exposure to high levels of air pollution with peaks of particulate matter (PM) concentration. Being exposed to elevated levels of PM reduces the effectiveness of the immune system and allows microorganisms to become more invasive (Yang et al. 2020). Current studies show that atmospheric particles could up-regulate the SARS-CoV-2 receptor and related protease (Cao et al. 2021). Any exposure to aerosol pollution can be related to different cardiovascular and respiratory diseases (Pun et al. 2017) via various mechanisms such as the up-regulation of Angiotensin-Converting Enzyme 2 (ACE-2) and Transmembrane Serine Protease 2 (TMPRSS2) (Lin et al. 2018; Paital and Agrawal 2020). The protective mechanism of ACE-2 upregulation helps the respiratory system maintain the Renin Angiotensin System (RAS) and decreases the inflammatory reaction (Ye and Liu 2019). It is not only abundantly expressed in the lungs, but in the glandular cells of duodenal, gastric, and rectal epithelia of the infected people by COVID-19 (Cao et al. 2021; Paital and Agrawal 2020; Wu et al. 2020). The ACE-2 acts as the primary receptor protein of SARS-CoV-2.

Additionally, the high affinity between the virus's synaptic glycoprotein and ACE-2 in host cell targets was reported (Vankadari and Wilce 2020). Also, TMPRSS2 acts as a protease, cleaving viral spike protein and combining it with host cells to accelerate the infection (Kaur et al. 2021). When particulate matter, especially $\mathrm{PM}_{2.5}$, attacks the human body, it can increase SARS-CoV-2 susceptibility for the human body by promoting the AEC-2 expression and its co-factor, TMPRSS2 (Kim et al. 2020). A recent in vivo study in mice showed a significant increase in the level of the AEC-2 expression after being exposed to $\mathrm{PM}_{2.5}$ (Cao et al. 2021; Lin et al. 2018). Statistical analysis suggests a significant association between PM concentrations, ACE-2 expression, and severity of COVID-19 infection (Cao et al. 2021; Paital and Agrawal 2020). Therefore, it is recommended to conduct further studies paying particular attention to the level of air pollution in areas highly hit by COVID-19 and introduce suitable measures by decision-makers to decrease the level of air pollution. Bontempi (2020) reported notable registered positive cases in Italy (mainly in Brescia and Bergamo areas, Lombardy) after a $\mathrm{PM}_{10}$ episode exceeding the set safety limit of $50 \mu \mathrm{g} / \mathrm{m}^{3}$ for several days at the beginning of March 2020. However, a direct linkage between $\mathrm{PM}_{10}$ peak 

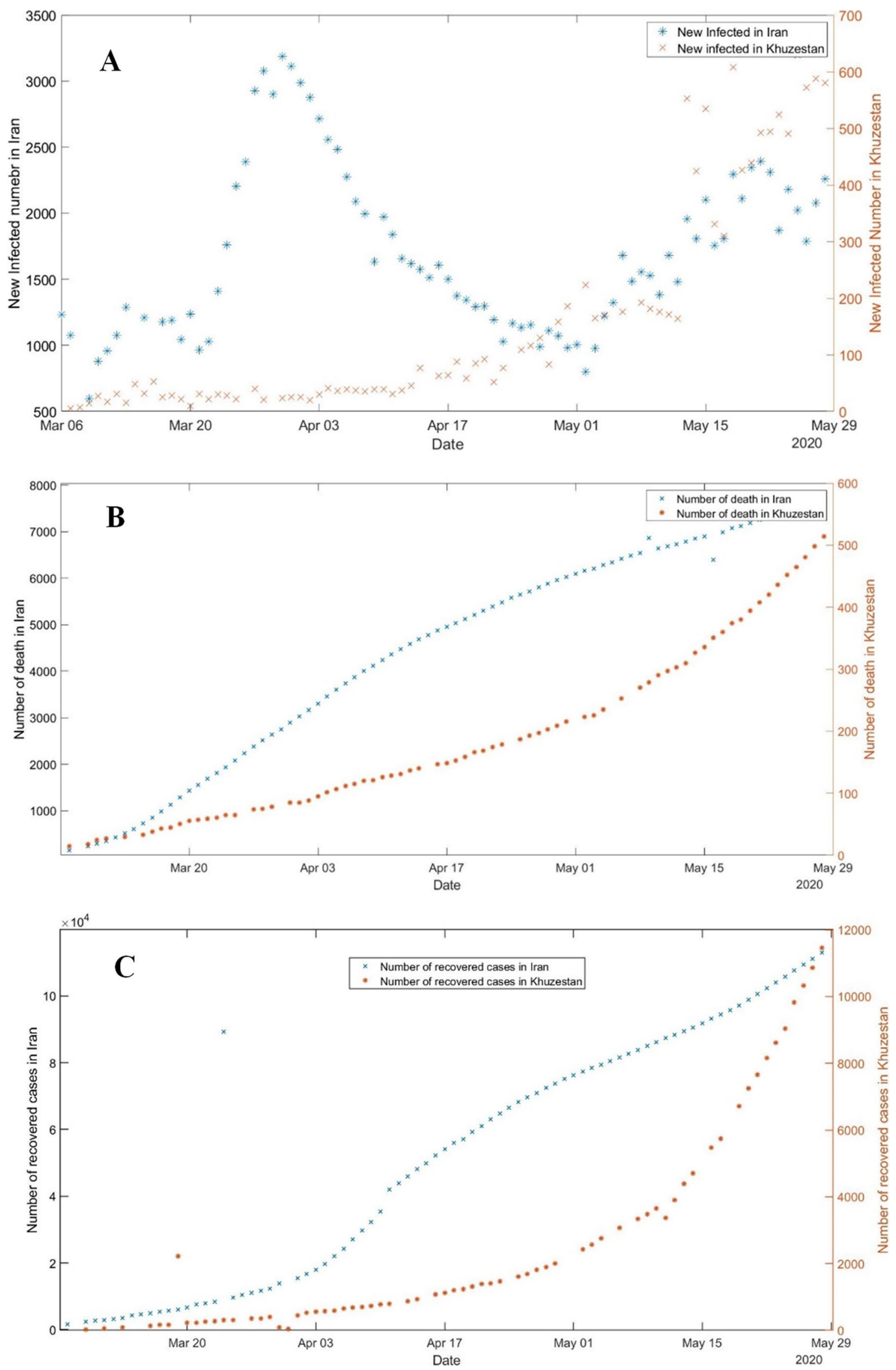
4 Fig. 5 (A) The total number of infected people, (B) the total number of deaths, and (C) the total number of recovered people in Iran and Khuzestan province, starting from $6^{\text {th }}$ March 2020 to $28^{\text {th }}$ May 2020

and COVID-19 diffusion was not reported (Bontempi 2020). Other related studies, summarized in Table 5, supported the hypothesis that any increase in the spread of COVID-19 and related mortality could be due to poor air quality. Specifically, a positive association was observed among PM, focusing on PM2.5 and COVID-19 mortality or morbidity. Based on their studies, long-term exposure to a relatively high level of particulate matter may be responsible for the spread and pathogenicity of SARS-CoV-2.

This paper suggests that the captured impacts in our study can be related primarily to co-morbidities, inflammation, pre-existing Particulate Matter-related cellular damage, and up-regulation of ACE-2 \& TMPRSS2 in the host cells (Cao et al. 2021; Ciencewicki and Jaspers 2007; Kim et al. 2020; Paital and Agrawal 2020; Pope 3rd et al. 2016; Tsai et al. 2019). Previous studies also reported that air pollution exposure could negatively affect early responses of the immune system to the infection, which leads to later increases in worse prognosis and inflammation (Ciencewicki and Jaspers 2007; Conticini et al. 2020; Lambert et al. 2003), a possible alternative explanation for our findings.

A great concern is the presence of pathogenic microorganisms in the air and their transportation by ambient PM. It is essential to identify the potential impacts of airborne virus exposure caused by PM. During a MED event, these findings in Khuzestan, in combination with recently conducted studies of viral interactions with particulate matter, raise suspicion about the probable airborne transmission of COVID-19. As a result, any association between human health and air pollution, especially particulate matter, is vital to formulate positive strategies by policymakers to decrease atmospheric aerosols and potentially reduce the spread of future epidemic viruses and illnesses.

Unfortunately, during a pandemic, it is impossible to design a study and collect ideal quality temporal and spatial data to minimize sources of bias. As a result, our research has some limitations, and further investigations are required. We only focused on the correlations among AOD levels (representing inhalable particle levels in the studied cities)

Table 2 Cities in clusters based on features of AOD, Duration, PSC, PBLH, WS, and Population Density during studied period ( $1^{\text {st }}$ April $2020-5^{\text {th }}$ May 2020) in Khuzestan, Iran

\begin{tabular}{ll}
\hline Cluster & Cities \\
\hline 1 & Hendijan-Mahshahr-Ramshir-Omidiyeh-Behbahan \\
$\mathbf{2}$ & Karun-Abadan-Shushtar-Bavi-Shush-Ahvaz-Andimeshk \\
$\mathbf{3}$ & Rahmhormouz-Korramshahr-Dezful-Izeh-Bagh-e- \\
& Malek-Masjed Soleiman-Hoveizeh-Hamidiyeh \\
\hline
\end{tabular}

Table 3 The percentages of the included features in RFA based on meteorological (WS, Surface Pressure, Temp, PBLH, and RH) and air quality (AOD) data during studied period ( $1^{\text {st }}$ April $2020-5^{\text {th }}$ May 2020) in Khuzestan, Iran

\begin{tabular}{lll}
\hline Feature & Importance value & $\begin{array}{l}\text { \% of } \\
\text { importance } \\
\text { value }\end{array}$ \\
\hline AOD & 3.8082567 & 23 \\
Temperature & 2.8008748 & 17 \\
PBLH & 0.9373292 & 6 \\
Surface pressure & 3.0668876 & 18 \\
RH. & 0.9365382 & 6 \\
WS. & 5.2580563 & 31 \\
\hline
\end{tabular}

and the daily percentage increase of COVID-19 infection before, during, and after periods of a dust incursion event; this study did not focus on the association of air pollution on the COVID-19 pandemic. The data did not include medical history (no information on background health issues such as respiratory and cardiovascular conditions and diabetes), smoking status, or the age-specific or gender-specific confirmed COVID-19 cases, so no subgroup analyses on these factors could be conducted. We also could not include other factors in the analyses, such as indoor confinement duration, healthcare system capacity, and case identification procedures and practices. Also, our findings are not necessarily generalizable globally to other regions with dust intrusion events, given that we only had data in one region of Iran. Data on potential confounding factors such as the susceptibility of the population, surveillance data on respiratory infections, patterns of social relationships, public health measures, use of masks and sanitizers, hygiene, social distancing, virus resistance, mobility, urban density, socioeconomic variables were also not available for our study. Adjusting for these potential confounders can strengthen the findings for future studies.

Moreover, due to the lack of data, the current study was not able to construct generalized linear models with control variables such as autoregressive components, seasonality, and trend. Therefore, further studies are required with a sufficient length of data introducing the different waves of the pandemic to investigate the impacts of the combination of air pollution, climate variability, and other factors extrinsic to COVID-19. Since dust intrusion is associated with a decreased mixing layer height, we recommend in further studies to investigate the impact of other pollutants and also constitutes of particulate matter $\left(\mathrm{PM}_{10}\right.$ and $\left.\mathrm{PM}_{2.5}\right)$, which can also be linked to the severity and incidence of COVID19 (Frontera et al. 2020; Pandolfi et al. 2014; Salvador et al. 2019; Yao et al. 2020b; Zoran et al. 2020). It is worth mentioning that reduced mixing layer height not only increases 


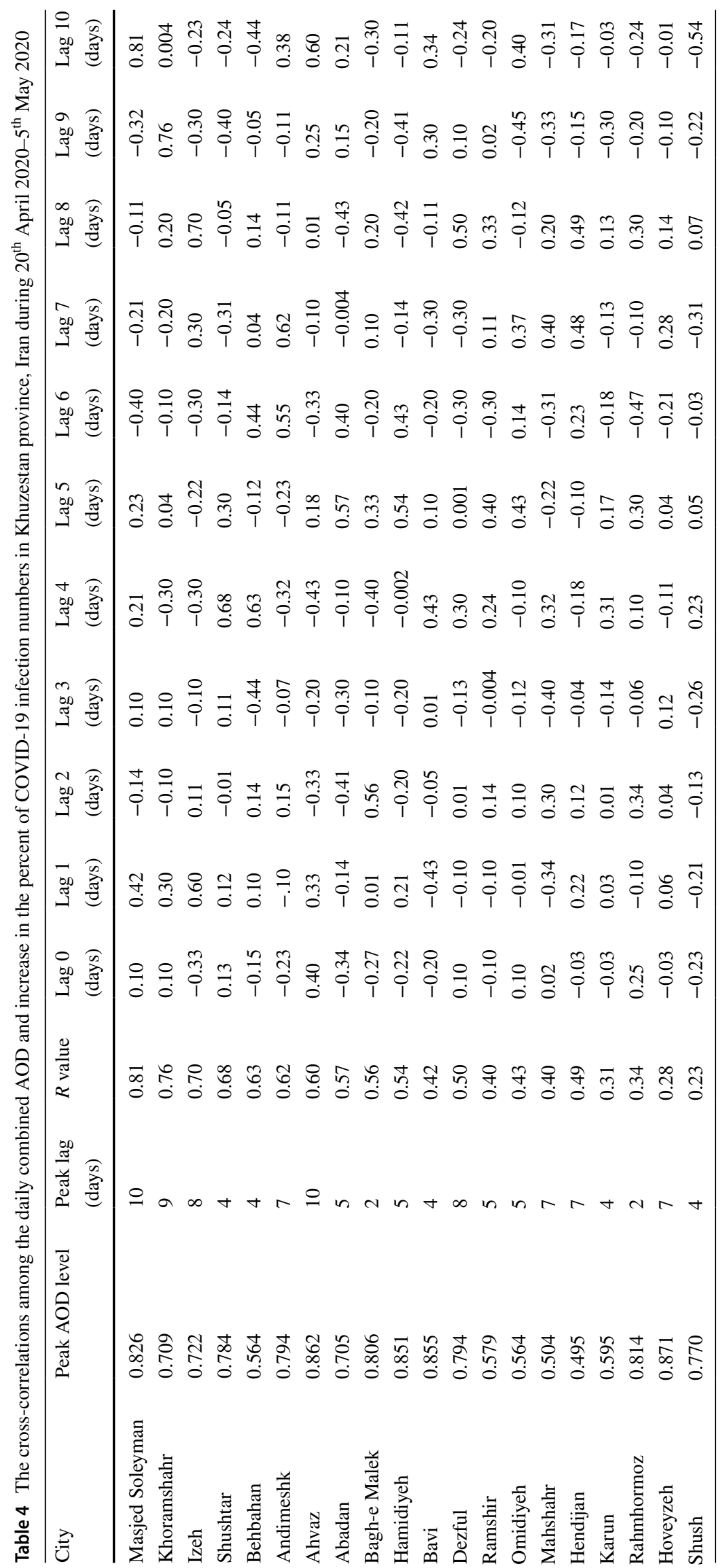




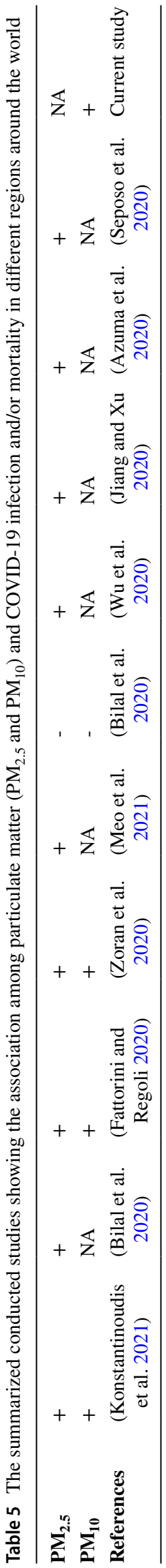

the level of primary pollutants but also can make the dispersion of other pollutants more difficult (Li et al. 2017).

Health and environmental data on the ground in real time is almost always incomplete, if not entirely unavailable. Yet, to respond promptly to the demand of pandemics and to conduct short-term projections of disease incidence and death that can inform the planning for required beds, ventilators, and medicines, we require that data. The innovative utilization of satellite remote sensing for making projections following dust storms may provide that data and save lives. Our study is the first such application as a potential tool to inform the planning for the current pandemic and future epidemics in a timely manner.

\section{Conclusion}

Sparse earlier research has demonstrated a positive correlation between MED intrusion and health impacts in downwind areas. The subsequent global growth of the number of confirmed COVID-19 cases, the potential causal association of diffusion of COVID-19 with air pollution and dust intrusion was proposed. For the first time, this paper investigated the correlation between dust intrusion and daily increase in COVID-19 infection counts in Khuzestan, Iran, following the Middle East Dust (MED) intrusion of April 2020, when $\mathrm{PM}_{10}$ pollution occurred for several days. In Khuzestan, only after a 7-day lag, the recorded number of new cases tripled, showing a significant abnormal increase in the province's daily disease rate. A direct correlation between the elevated daily combined AOD and an increase in the percentage of COVID-19 infection numbers was evident in the region, starting from 20/04/2020 to 09/05/2020. A Pearson correlation coefficient analysis shows that combined daily AOD in the studied cities of Khuzestan, Iran, was significantly positively associated with diurnal average wind speed, temperature, and the Planetary Boundary Layer. Also, RF analysis showed the critical role of wind speed and AOD with the relative correlation coefficient values of 0.31 and 0.23 , respectively, influencing the daily increased percent of COVID-19 disease counts. This first study may serve as a reference to better understanding and predicting the factors affecting COVID-19 transmission and diffusion routes, focusing on the MED intrusions' role. Moreover, the findings can serve to support the adoption of public health measures to protect vulnerable population groups such as people with previous pathologies and the elderly by advising them to reduce their exposure to outdoor air pollution during dust intrusions.

Supplementary Information The online version contains supplementary material available at https://doi.org/10.1007/s11356-021-18195-7. 
Acknowledgements The authors are most grateful to the Department of Environment, Iran's relevant officials, for providing the required data in this research. The authors gratefully acknowledge the NOAA Air Resources Laboratory (ARL) to provide the HYSPLIT transport and dispersion model and/or READY website (http://www.ready.noaa. gov) used in this publication.

Author contribution PB: conceptualisation, methodology, data analysis, writing - original draft preparation. BC: methodology, data analysis, writing-reviewing, and editing. AJ: data preparation and processing, data analysis, and language editing. NJ: data analysis. AN: data preparation. MT: data preparation. JRK: supervision and project administration. NM: writing - reviewing and editing. FK: conceptualisation, methodology, data analysis, writing—reviewing, and editing.

Funding This project has received funding from the NU project (Nazarbayev Research Fund SOE2017004).

Data availability Data available on request from the authors.

Code availability Not applicable.

\section{Declarations}

Ethics approval Not applicable.

Consent to participate Not applicable.

Consent for publication Not applicable.

Conflict of interest The authors declare no competing interests.

\section{References}

Aliabadi K, Asadi Zanganeh M, Dadashi Roudbari A (2015) Evaluation and monitoring dust storm by remote sensing (case study: west and southwest of Iran). Sci J Rescue Reli 7:1-20

Alizadeh-Choobari O, Ghafarian P, Owlad E (2016) Temporal variations in the frequency and concentration of dust events over Iran based on surface observations. Int J Climatol 36:2050-2062. https://doi.org/10.1002/joc.4479

Al-Taiar A, Thalib L (2014) Short-term effect of dust storms on the risk of mortality due to respiratory, cardiovascular and all-causes in Kuwait. Int J Biometeorol 58:69-77. https://doi.org/10.1007/ s00484-012-0626-7

Ashrafi K, Shafiepour-Motlagh M, Aslemand A, Ghader S (2014) Dust storm simulation over Iran using HYSPLIT. J Environ Health Sci Eng 12:9. https://doi.org/10.1186/2052-336X-12-9

Azuma K, Kagi N, Kim H, Hayashi M (2020) Impact of climate and ambient air pollution on the epidemic growth during COVID-19 outbreak in Japan. Environ Res 190:110042. https://doi.org/10. 1016/j.envres.2020.110042

Baghbanan P, Ghavidel Y, Farajzadeh M (2020) Temporal long-term variations in the occurrence of dust storm days in Iran. Meteorog Atmos Phys. https://doi.org/10.1007/s00703-020-00728-3

Bart O, Aurelio T, Xavier Q, Andrés A, Fulvio A, Jorge P, Noemí P, Jordi S (2011) The effects of particulate matter sources on daily mortality: a case-crossover study of Barcelona, Spain. Environ Health Perspect 119:1781-1787. https://doi.org/10.1289/ehp. 1103618
Behzad H, Mineta K, Gojobori T (2018) Global ramifications of dust and sandstorm microbiota. Genome Biol Evol 10. https://doi. org/10.1093/gbe/evy 134

Bilal, Bashir MF, Benghoul M, Numan U, Shakoor A, Komal B, Bashir MA, Bashir M, Tan D (2020) Environmental pollution and COVID-19 outbreak: insights from Germany. Air Qual Atmos Health 1-10. https://doi.org/10.1007/ s11869-020-00893-9

Bontempi E (2020) First data analysis about possible COVID-19 virus airborne diffusion due to air particulate matter (PM): the case of Lombardy (Italy). Environ Res 186:109639. https://doi.org/10. 1016/j.envres.2020.109639

Bourouiba L (2020) Turbulent gas clouds and respiratory pathogen emissions: potential implications for reducing transmission of COVID-19. JAMA 323:1837-1838. https://doi.org/10.1001/ jama.2020.4756

Brindley H, Knippertz P, Ryder C, Ashpole I (2012) A critical evaluation of the ability of the Spinning Enhanced Visible and Infrared Imager (SEVIRI) thermal infrared red-green-blue rendering to identify dust events: theoretical analysis. J Geophys Res 117:7201. https://doi.org/10.1029/2011JD017326

Broomandi P, Bakhtiar Pour A (2017) Dust source identification using physical-chemical characterization and numerical modeling in Masjed Soleyman. Iran J Health Environ 9:517-526

Broomandi P, Rashidi Y (2018) The effect of dust storm on the microbial quality of ambient air in Ahvaz city and dust source identification using numerical modeling. Environ Sci 16:49-64

Cao H, Amiraslani F, Liu J, Zhou N (2015) Identification of dust storm source areas in West Asia using multiple environmental datasets. Sci Total Environ 502:224-235. https://doi.org/10.1016/J.SCITO TENV.2014.09.025

Cao Y, Shao L, Jones T, Oliveira MLS, Ge S, Feng X, Silva LFO, BéruBé K (2021) Multiple relationships between aerosol and COVID-19: a framework for global studies. Gondwana Res 93:243-251. https://doi.org/10.1016/j.gr.2021.02.002

Chen PS, Tsai F, Lin C, Yang CY, Chan CC, Young CY, Lee CH (2010) Ambient influenza and avian influenza virus during dust storm days and background days. Environ Health Perspect 118:12111216. https://doi.org/10.1289/ehp.0901782

Chen G, Zhang W, Li S, Williams G, Liu C, Morgan GG, Jaakkola JJK, Guo Y (2017) Is short-term exposure to ambient fine particles associated with measles incidence in China? A multi-city study. Environ Res 156:306-311. https://doi.org/10.1016/j.envres.2017. 03.046

Ciencewicki J, Jaspers I (2007) Air pollution and respiratory viral infection. Inhal Toxicol 19:1135-1146. https://doi.org/10.1080/ 08958370701665434

Conticini E, Frediani B, Caro D (2020) Can atmospheric pollution be considered a co-factor in extremely high level of SARS-CoV-2 lethality in Northern Italy? Environ Pollut 261:114465. https:// doi.org/10.1016/j.envpol.2020.114465

Delangizan S, Jafari Motlagh Z (2013) Dust phenomenon affects on cardiovascular and respiratory hospitalizations and mortality A case study in Kermanshah, during March-September 2010-2011. Iran J Health Environ 6:65-76

Després V, Huffman JA, Burrows SM, Hoose C, Safatov A, Buryak G, Fröhlich-Nowoisky J, Elbert W, Andreae M, Pöschl U, Jaenicke R (2012) Primary biological aerosol particles in the atmosphere: a review. Tellus Ser B Chem Phys Meteorol 64:15598. https:// doi.org/10.3402/tellusb.v64i0.15598

Doğan B, Ben Jebli M, Shahzad K, Farooq TH, Shahzad U (2020) Investigating the effects of meteorological parameters on COVID-19: case study of New Jersey, United States. Environ Res 191:110148. https://doi.org/10.1016/j.envres.2020.110148

Domingo JL, Marquès M, Rovira J (2020) Influence of airborne transmission of SARS-CoV-2 on COVID-19 pandemic. A 
review. Environ Res 188:109861. https://doi.org/10.1016/j. envres.2020.109861

Draxler R, Hess G, (1997). Description of the HYSPLIT_4 modelling system. NOAA Tech. Mem. ERL ARL-224.

Escudero M, Querol X, Pey J, Alastuey A, Pérez N, Ferreira F, Alonso S, Rodríguez S, Cuevas E (2007) A methodology for the quantification of the net African dust load in air quality monitoring networks. Atmos Environ 41:5516-5524. https:// doi.org/10.1016/j.atmosenv.2007.04.047

Fattorini D, Regoli F (2020) Role of the chronic air pollution levels in the Covid-19 outbreak risk in Italy. Environ Pollut 264:114732. https://doi.org/10.1016/j.envpol.2020.114732

Food and Drug Association (n.d.), available at https://www.fda.gov. ir/.

Fromme H, Diemer J, Dietrich S, Cyrys J, Heinrich J, Lang W, Kiranoglu M, Twardella D (2008) Chemical and morphological properties of particulate matter (PM10, PM2.5) in school classrooms and outdoor air. Atmos Environ 42:6597-6605. https://doi.org/ 10.1016/j.atmosenv.2008.04.047

Frontera A, Cianfanelli L, Vlachos K, Landoni G, Cremona G (2020) Severe air pollution links to higher mortality in COVID-19 patients: the "double-hit" hypothesis. J Inf Secur 81:255-259. https://doi.org/10.1016/j.jinf.2020.05.031

Geravandi S, Sicard P, Khaniabadi YO, De Marco A, Ghomeishi A, Goudarzi G, Mahboubi M, Yari AR, Dobaradaran S, Hassani G, Mohammadi MJ, Sadeghi S (2017) A comparative study of hospital admissions for respiratory diseases during normal and dusty days in Iran. Environ Sci Pollut Res 24:18152-18159. https://doi. org/10.1007/s11356-017-9270-4

Gholamzade Ledari D, Hamidi M, Shao Y (2020) Evaluation of the 13 April 2011 frontal dust storm in west Asia. Aeolian Res 44:100592. https://doi.org/10.1016/j.aeolia.2020.100592

Givehchi R, Arhami M, Tajrishy M (2013) Contribution of the Middle Eastern dust source areas to PM10 levels in urban receptors: case study of Tehran, Iran. Atmos Environ 75:287-295. https://doi. org/10.1016/j.atmosenv.2013.04.039

Gonzalez-Toril E, Osuna S, Viúdez-Moreiras D, Navarro-Cid I, Toro S, Sor S, Mora R, Puente-Sánchez F, de Diego Castilla G, Aguilera A (2020) Impacts of Saharan dust intrusions on bacterial communities of the low troposphere. Sci Rep 10(1):1-13. https://doi. org/10.1038/s41598-020-63797-9

Goudarzi G, Shirmardi M, Khodarahmi F, Hashemi Shahraki A, Alavi N, Ankali K, Babaei A, Soleimani Z, Marzouni M (2014) Particulate matter and bacteria characteristics of the Middle East Dust (MED) storms over Ahvaz, Iran. Aerobiologia (Bologna) 30:1-12. https://doi.org/10.1007/s10453-014-9333-7

Goudarzi G, Alavi N, Geravandi S, Idani E, Behrooz HRA, Babaei AA, Alamdari FA, Dobaradaran S, Farhadi M, Mohammadi MJ (2018) Health risk assessment on human exposed to heavy metals in the ambient air PM10 in Ahvaz, southwest Iran. Int J Biometeorol 62:1075-1083. https://doi.org/10.1007/s00484-018-1510-x

Grace K, Rajkumar M, Devasena MSG, Rajathi S, Usha K, Raabiathul B, (2016). Air pollution analysis using enhanced K-Means clustering algorithm for real time sensor data. https://doi.org/10. 1109/TENCON.2016.7848362

Guan Q, Sun X, Yang J, Pan B, Zhao S, Wang L (2017) Dust storms in northern China: long-term spatiotemporal characteristics and climate controls. J Clim 30:6683-6700. https://doi.org/10.1175/ JCLI-D-16-0795.1

Guan W-J, Ni Z, Hu Y, Liang W, Ou C-Q, He J, Liu L, Shan H, Lei C, Hui D, Du B, Li L, Zeng G, Yuen K-Y, Chen R, Tang C, Wang T, Chen P, Xiang J, Zhong N, (2020). Clinical characteristics of 2019 novel coronavirus infection in China. https://doi.org/10. 1101/2020.02.06.20020974

Hadei M, Hopke PK, Jonidi A, Shahsavani A (2020) A letter about the airborne transmission of SARS-CoV-2 based on the current evidence. Aerosol Air Qual Res 20:911-914. https://doi.org/10. 4209/aaqr.2020.04.0158

Hamidi M (2019) Atmospheric investigation of frontal dust storms in southwest Asia. Asia-Pac J Atmos Sci 55:177-193. https://doi. org/10.1007/s13143-018-0083-2

Hamzeh, Nasim H, Karami S, Kaskaoutis DG, Tegen I, Moradi M, Opp C (2021a) Atmospheric dynamics and numerical simulations of six frontal dust storms in the Middle East region. Atmospheric. https://doi.org/10.3390/atmos12010125

Hamzeh, Hossein N, Karami S, Opp C, Fattahi E, Jean-François V (2021b) Spatial and temporal variability in dust storms in the Middle East, 2002-2018: three case studies in July 2009. Arab J Geosci 14:538. https://doi.org/10.1007/s12517-021-06859-0

Hennen M, White KH, Shahgedanova M (2019) An assessment of SEVIRI imagery at various temporal resolutions and the effect on accurate dust emission mapping. Remote Sens 11:918. https:// doi.org/10.3390/rs11080918

Hu X, Waller LA, Al-Hamdan MZ, Crosson WL, Estes MG, Estes SM, Quattrochi DA, Sarnat JA, Liu Y (2013) Estimating ground-level PM2.5 concentrations in the southeastern US using geographically weighted regression. Environ Res 121:1-10. https://doi.org/ 10.1016/j.envres.2012.11.003

Iranian meteorological organization (n.d.), available at https://www. irimo.ir/eng/index.php.

Jayaweera M, Perera H, Gunawardana B, Manatunge J (2020) Transmission of COVID-19 virus by droplets and aerosols: a critical review on the unresolved dichotomy. Environ Res 188:109819. https://doi.org/10.1016/j.envres.2020.109819

Jiang Y, Xu J (2020) The association between COVID-19 deaths and short-term ambient air pollution/meteorological condition exposure: a retrospective study from Wuhan, China. Air Qual Atmos Health 14:1-5. https://doi.org/10.1007/s11869-020-00906-7

Kai T, Huang Z, Huang J, Maki T, Zhang S, Ma X, Shi J, Jianrong B, Zhou T, Wang G, Zhang L (2017) Characterization of atmospheric bioaerosols along the transport pathway of Asian dust during the Dust-Bioaerosol 2016 Campaign. Atmos Chem Phys Discuss 1-41. https://doi.org/10.5194/acp-2017-1172

Kaur T, Kapila S, Kapila R, Kumar S, Upadhyay D, Kaur M, Sharma C (2021) Tmprss2 specific miRNAs as promising regulators for SARS-CoV-2 entry checkpoint. Virus Res 294:198275. https:// doi.org/10.1016/j.virusres.2020.198275

Kim J-H, Kim J, Kim WJ, Choi YH, Yang S-R, Hong S-H (2020) Diesel particulate matter 2.5 induces epithelial-to-mesenchymal transition and upregulation of SARS-CoV-2 receptor during human pluripotent stem cell-derived alveolar organoid development. Int J Environ Res Public Health 17:8410. https://doi.org/ 10.3390/ijerph17228410

Klingmüller K, Pozzer A, Metzger S, Stenchikov GL, Lelieveld J (2016) Aerosol optical depth trend over the Middle East. Atmos Chem Phys 16:5063-5073. https://doi.org/10.5194/ acp-16-5063-2016

Konstantinoudis G, Padellini T, Bennett J, Davies B, Ezzati M, Blangiardo M (2021) Long-term exposure to air-pollution and COVID19 mortality in England: a hierarchical spatial analysis. Environ Int 146:106316. https://doi.org/10.1016/j.envint.2020.106316

Lambert AL, Trasti FS, Mangum JB, Everitt JI (2003) Effect of preexposure to ultrafine carbon black on respiratory syncytial virus infection in mice. Toxicol Sci 72:331-338. https://doi.org/10. 1093/toxsci/kfg031

Lauer SA, Grantz KH, Bi Q, Jones FK, Zheng Q, Meredith HR, Azman AS, Reich NG, Lessler J (2020) The incubation period of coronavirus disease 2019 (COVID-19) from publicly reported confirmed cases: estimation and application. Ann Intern Med 172:577-582. https://doi.org/10.7326/M20-0504

Lee HJ, Liu Y, Coull B, Schwartz J, Koutrakis P (2011) A novel calibration approach of MODIS AOD data to predict PM 2.5 
concentrations. ACPD Chem Phys Discuss 11:9769-9795. https://doi.org/10.5194/acp-11-7991-2011

Li Z, Guo J, Ding A, Liao H, Liu J, Sun Y, Wang T, Xue H, Zhang H, Zhu B (2017) Aerosol and boundary-layer interactions and impact on air quality. Natl Sci Rev 4:810-833. https://doi.org/ 10.1093/nsr/nwx 117

Li L, Huang Q, Wang DC, Ingbar DH, Wang X (2020) Acute lung injury in patients with COVID-19 infection. Clin Transl Med 10:20-27. https://doi.org/10.1002/ctm2.16

Lin C-I, Tsai C-H, Sun Y-L, Hsieh W-Y, Lin Y-C, Chen C-Y, Lin C-S (2018) Instillation of particulate matter 2.5 induced acute lung injury and attenuated the injury recovery in ACE2 knockout mice. Int J Biol Sci 14:253-265. https://doi.org/10.7150/ijbs. 23489

Linares C, Culqui D, Belda F, López-Bueno JA, Luna Y, SánchezMartínez G, Hervella B, Díaz J (2021) Impact of environmental factors and Sahara dust intrusions on incidence and severity of COVID-19 disease in Spain. Effect in the first and second pandemic waves. Environ Sci Pollut Res Int 28:51948-51960. https://doi.org/10.1007/s11356-021-14228-3

Malamiri N, Rashkib A, Hosseinzadeh SR, Jahadi Toroghi M (2019) Identification of desert dust sources in the West Khuzestan Province using of brightness temperature algorithms. Geogr Environ Hazards 8:27-30

MalAmiri N, Rashki A, Hosseinzadeh SR, Kaskaoutis DG (2022) Mineralogical, geochemical, and textural characteristics of soil and airborne samples during dust storms in Khuzestan, southwest Iran. Chemosphere 286:131879. https://doi.org/10.1016/j. chemosphere.2021.131879

Marsham JH, Hobby M, Allen CJT, Banks JR, Bart M, Brooks BJ, Cavazos-Guerra C, Engelstaedter S, Gascoyne M, Lima AR, Martins JV, Mc Quaid JB, O'Leary A, Ouchene B, Ouladichir A, Parker DJ, Saci A, Salah-Ferroudj M, Todd MC, Washington R (2013) Meteorology and dust in the central Sahara: observations from Fennec supersite-1 during the June 2011 Intensive Observation Period. J Geophys Res Atmos 118:4069-4089. https://doi.org/10.1002/jgrd.50211

Martínez MA, Ruiz J, Cuevas E (2009) Use of SEVIRI images and derived products in a WMO Sand and dust Storm Warning System. IOP Conf Ser Earth Environ Sci 7:12004. https://doi. org/10.1088/1755-1307/7/1/012004

Meo SA, Abukhalaf AA, Alomar AA, Alessa OM, Sami W, Klonoff DC (2021) Effect of environmental pollutants PM-2.5, carbon monoxide, and ozone on the incidence and mortality of SARSCOV-2 infection in ten wildfire affected counties in California. Sci Total Environ 757:143948. https://doi.org/10.1016/j.scito tenv. 2020.143948

Middleton N (2020) Health in dust belt cities and beyond-an essay by Nick Middleton. BMJ 371:m3089. https://doi.org/10.1136/ bmj.m3089

Miri M, Ebrahimi Aval H, Ehrampoush MH, Mohammadi A, Toolabi A, Nikonahad A, Derakhshan Z, Abdollahnejad A (2017) Human health impact assessment of exposure to particulate matter: an AirQ software modeling. Environ Sci Pollut Res 24:16513-16519. https://doi.org/10.1007/s11356-017-9189-9

Modarres M, Amiri M and Jackson C, (2017). Types of accelerated testing and modeling concepts. Probabilistic Phys. Fail. Approach to Reliab., Wiley Online Books. doi:https://doi.org/ 10.1002/9781119388692.ch3

Mohammadpour K, Siortino M, Saligheh M, Raziei T, Darvishi Boloorani A (2020) Spatiotemporal regionalization of atmospheric dust based on multivariate analysis of MACC model over Iran. Atmos Res. https://doi.org/10.1016/j.atmosres.2020. 105322

Molinaro A, Carriero N, Bjornson R, Hartge P, Rothman N, Chatterjee N (2011) Power of data mining methods to detect genetic associations and interactions. Hum Hered 72:85-97. https://doi. org/10.1159/000330579

Morawska L, Cao J (2020) Airborne transmission of SARS-CoV-2: the world should face the reality. Environ Int 139:105730. https://doi. org/10.1016/j.envint.2020.105730

Nabavi SO, Haimberger L, Abbasi E (2018) Assessing PM2.5 concentrations in Tehran, Iran, from space using MAIAC, deep blue, and dark target AOD and machine learning algorithms. Atmos Pollut Res. https://doi.org/10.1016/j.apr.2018.12.017

Namdari S, Karimi N, Sorooshian A, Mohammadi G, Sehatkashani S (2018) Impacts of climate and synoptic fluctuations on dust storm activity over the Middle East. Atmos Environ (1994) 173:265-276. https://doi.org/10.1016/j.atmosenv.2017.11.016

Neisi A, Dastoorpoor M, Goudarzi G, Borsi S-H, Attar G, Attar S (2019) The impact of dusty days on fungi spores: hot vs. cold seasons of Ahvaz, Iran. Health Scope In Press. https://doi.org/ 10.5812/jhealthscope. 80284

Neophytou AM, Yiallouros P, Coull BA, Kleanthous S, Pavlou P, Pashiardis S, Dockery DW, Koutrakis P, Laden F (2013) Particulate matter concentrations during desert dust outbreaks and daily mortality in Nicosia, Cyprus. J Expo Sci Environ Epidemiol 23:275-280. https://doi.org/10.1038/jes.2013.10

Niu J, Rasmussen P, Wheeler A, Williams R, Chénier M (2010) Evaluation of airborne particulate matter and metals data in personal, indoor and outdoor environments using ED-XRF and ICP-MS and co-located duplicate samples. Atmos Environ 44:235-245. https://doi.org/10.1016/j.atmosenv.2009.10.009

Nourmoradi H, Moradnejadi K, Moghadam F, Khosravi B, Hemati L, Khoshniyat R, Kazembeigi F (2015) The Effect of Dust Storm on the Microbial Quality of Ambient Air in Sanandaj: A City Located in the West of Iran. Global J Health Sci 7. https://doi. org/10.5539/gjhs.v7n7p114

Paital B, Agrawal PK (2020) Air pollution by NO2 and PM2.5 explains COVID-19 infection severity by overexpression of angiotensinconverting enzyme 2 in respiratory cells: a review. Environ Chem Lett. https://doi.org/10.1007/s10311-020-01091-w

Pandolfi M, Tobias A, Alastuey A, Sunyer J, Schwartz J, Lorente J, Pey J, Querol X (2014) Effect of atmospheric mixing layer depth variations on urban air quality and daily mortality during Saharan dust outbreaks. Sci Total Environ 494-495:283-289. https://doi. org/10.1016/j.scitotenv.2014.07.004

Peng L, Zhao X, Tao Y, Mi S, Huang J, Zhang Q (2020) The effects of air pollution and meteorological factors on measles cases in Lanzhou, China. Environ Sci Pollut Res 27:13524-13533. https:// doi.org/10.1007/s11356-020-07903-4

Piazzalunga A, Barbieri P, Rizzo E, Gianluigi M, de Gennaro, A Di Gilio, A, Buono JP, Fornari P, Setti G, Fabrizio L, Passarini, M.G.P., 2020. Evaluation of the potential relationship between Particulate Matter (PM) pollution and COVID-19 infection spread in Italy. Ital. Soc. Environ. Med.

Pirsaheb M, Bakhshi S, Almasi A, Mousavi SA, Rezaei M, Sharafi H, Saleh E (2016) Evaluating the effect of meteorological parameters (humidity,temperature, wind speed and pressure) on the dust phenomenon - case study: Kermanshah, Iran (2008-2012). Int J Pharm Technol 8:17847-17855

Pope CA 3rd, Bhatnagar A, McCracken JP, Abplanalp W, Conklin DJ, O'Toole T (2016) Exposure to fine particulate air pollution is associated with endothelial injury and systemic inflammation. Circ Res 119:1204-1214. https://doi.org/10.1161/CIRCR ESAHA.116.309279

Pun VC, Kazemiparkouhi F, Manjourides J, Suh H (2017) Long-term PM2.5 exposures and respiratory, cancer and cardiovascular mortality in American older adults. Am J Epidemiol 186:961-969. https://doi.org/10.1093/aje/kwx166

Rahmani AR, Leili M, Azarian G, Poormohammadi A (2020) Sampling and detection of corona viruses in air: a mini review. Sci 
Total Environ 740:140207. https://doi.org/10.1016/j.scitotenv. 2020.140207

Rashki A, Kaskaoutis DG, Francois P, Kosmopoulos PG, Legrand M (2015) Dust-storm dynamics over Sistan region, Iran: seasonality, transport characteristics and affected areas. Aeolian Res 16:35-48. https://doi.org/10.1016/J.AEOLIA.2014.10.003

Rashki A, Middleton N, Goudie A (2021) Dust storms in Iran-distribution, causes, frequencies and impacts. Aeolian Res 48:100655. https://doi.org/10.1016/j.aeolia.2020.100655

Reche I, D'Orta G, Mladenov N, Winget DM, Suttle CA (2018) Deposition rates of viruses and bacteria above the atmospheric boundary layer. ISME J 12:1154-1162. https://doi.org/10.1038/ s41396-017-0042-4

Rodriguez S, Alastuey A, Alonso-Pérez S, Querol X, Cuevas E, AbreuAfonso J, Viana M, Pérez N, Pandolfi M, de la Rosa J (2011) Transport of desert dust mixed with North African industrial pollutants in the subtropical Saharan Air Layer. Atmos Chem Phys 11:6663-6685. https://doi.org/10.5194/acp-11-6663-2011

Rohrer M, Flahault A, Stoffel M (2020) Peaks of fine particulate matter may modulate the spreading and virulence of COVID19. Earth Syst Environ 4:789-796. https://doi.org/10.1007/ s41748-020-00184-4

Salmabadi H, Khalidy R, Saeedi M (2020) Transport routes and potential source regions of the Middle Eastern dust over Ahvaz during 2005-2017. Atmos Res 241:104947. https://doi.org/10.1016/j. atmosres.2020.104947

Salvador P, Molero F, Fernández A, Tobias A, Pandolfi M, GómezMoreno F, Barreiro M, Perez N, Marco I, Revuelta M, Querol X, Artíñano B (2019) Synergistic effect of the occurrence of African dust outbreaks on atmospheric pollutant levels in the Madrid metropolitan area. Atmos Res 226:208-218. https://doi.org/10. 1016/j.atmosres.2019.04.025

Sandra M, Massimo S, Annunziata F, Paolo GG, Achille M, Francesco F (2011) Saharan dust and associations between particulate matter and daily mortality in Rome, Italy. Environ Health Perspect 119:1409-1414. https://doi.org/10.1289/ehp.1003026

Seposo X, Ueda K, Sugata S, Yoshino A, Takami A (2020) Short-term effects of air pollution on daily single- and co-morbidity cardiorespiratory outpatient visits. Sci Total Environ 729:138934. https://doi.org/10.1016/j.scitotenv.2020.138934

Setti L, Passarini F, De Gennaro G, Barbieri P, Perrone MG, Piazzalunga A, Borelli M, Palmisani J, Di Gilio A, Piscitelli P, Miani A (2020) The potential role of particulate matter in the spreading of COVID-19 in Northern Italy: First Evidence-based Research Hypotheses. medRxiv. https://doi.org/10.1101/2020.04.11.20061 713

Shafiee M, Feghhi SAH, Rahighi J (2016a) Numerical analysis of the beam position monitor pickup for the Iranian Light Source Facility. Nucl Instrum Methods Phys Res Sect A Accel Spectrometers, Detect Assoc Equip 847:162-170. https://doi.org/10.1016/j.nima. 2016.11.065

Shafiee M, Feghhi SAH, Rahighi J (2016b) Analysis of de-noising methods to improve the precision of the ILSF BPM electronic readout system. J Instrum 11:P12020-P12020. https://doi.org/ 10.1088/1748-0221/11/12/p12020

Shahsavani A, Naddafi K, Jafarzade Haghighifard N, Mesdaghinia A, Yunesian M, Nabizadeh R, Arahami M, Sowlat MH, Yarahmadi M, Saki H, Alimohamadi M, Nazmara S, Motevalian SA, Goudarzi G (2012) The evaluation of PM10, PM2.5, and PM1 concentrations during the Middle Eastern Dust (MED) events in Ahvaz, Iran, from April through September 2010. J Arid Environ 77:72-83. https://doi.org/10.1016/j.jaridenv.2011.09.007

Shahsavani A, Tobías A, Querol X, Stafoggia M, Abdolshahnejad M, Mayvaneh F, Guo Y, Hadei M, Saeed Hashemi S, Khosravi A, Namvar Z, Yarahmadi M, Emam B (2020) Short-term effects of particulate matter during desert and non-desert dust days on mortality in Iran. Environ Int 134:105299. https://doi.org/10. 1016/j.envint.2019.105299

Shahzad K, Farooq TH, Doğan B, Zhong Hu L, Shahzad U (2021) Does environmental quality and weather induce COVID-19: case study of Istanbul, Turkey. Environ Forensic 1-12. https://doi.org/ 10.1080/15275922.2021.1940380

Shobha N, Asha T, (2017). Monitoring weather based meteorological data: clustering approach for analysis. https://doi.org/10.1109/ ICIMIA.2017.7975575

Solomon S, Qin D, Manning M, Chen Z, Marquis M, Avery K, Tignor M, Miller H, (2007). Climate change 2007: the physical science basis. Working Group I Contribution to the Fourth Assessment Report of the IPCC.

Tsai D-H, Riediker M, Berchet A, Paccaud F, Waeber G, Vollenweider P, Bochud M (2019) Effects of short- and long-term exposures to particulate matter on inflammatory marker levels in the general population. Environ Sci Pollut Res 26:19697-19704. https://doi. org/10.1007/s11356-019-05194-y

Tüysüzoğlu G, Birant D, Pala A (2019) Majority voting based multitask clustering of air quality monitoring network in Turkey. Appl Sci 9:1610. https://doi.org/10.3390/app9081610

van Doremalen N, Bushmaker T, Morris DH, Holbrook MG, Gamble A, Williamson BN, Tamin A, Harcourt JL, Thornburg NJ, Gerber SI, Lloyd-Smith JO, de Wit E, Munster VJ (2020) Aerosol and surface stability of SARS-CoV-2 as compared with SARSCoV-1. N Engl J Med 382:1564-1567. https://doi.org/10.1056/ NEJMc2004973

Vankadari N, Wilce JA (2020) Emerging WuHan (COVID-19) coronavirus: glycan shield and structure prediction of spike glycoprotein and its interaction with human CD26. Emerg Microbes Infect. https://doi.org/10.1080/22221751.2020.1739565

Verweij PE, Gangneux J-P, Bassetti M, Brüggemann RJM, Cornely OA, Koehler P, Lass-Flörl C, van de Veerdonk FL, Chakrabarti A, Hoenigl M, European Confederation of Medical Mycology; International Society for Human and Animal Mycology; European Society for Clinical Microbiology and Infectious Diseases Fungal Infection Study Group; ESCMID Study Group for Infections in Critically Ill Patients (2020) Diagnosing COVID-19-associated pulmonary aspergillosis. Lancet Microbe 1:e53-e55. https://doi.org/10.1016/S2666-5247(20)30027-6

Wang H, Tian C, Wang W, Luo X (2019) Temporal cross-correlations between ambient air pollutants and seasonality of tuberculosis: a time-series analysis. Int J Environ Res Public Health 16:1585. https://doi.org/10.3390/ijerph16091585

Weil T, Filippo C, Albanese D, Donati C, Pindo M, Pavarini L, Carotenuto F, Pasqui M, Poto L, Gabrieli J, Barbante C, Sattler B, Cavalieri D, Miglietta F (2017) Legal immigrants: invasion of alien microbial communities during winter occurring desert dust storms. Microbiome 5:32. https://doi.org/10.1186/ s40168-017-0249-7

WHO (2007) Health relevance of particulate matter from various sources. Report on a WHO workshop, Bonn

Wickramasinghe N, Wallis M, Coulson S, Kondakov A, Steele E, Gorczynski R, Temple R, Tokoro G, Klyce B, Slijepcevic P (2020) Intercontinental spread of COVID-19 on global wind systems. Curr Res Virol 4:13. https://doi.org/10.37421/VirolCurrRes. 2020.4.113

Wigginton KR, Boehm AB (2020) Environmental engineers and scientists have important roles to play in stemming outbreaks and pandemics caused by enveloped viruses. Environ Sci Technol 54:3736-3739. https://doi.org/10.1021/acs.est.0c01476

Wu X, Nethery R, Benjamin M, Braun D, Dominici F (2020) Exposure to air pollution and COVID-19 mortality in the United States: a nationwide cross-sectional study. MedRxiv. https://doi.org/10. 1101/2020.04.05.20054502 
Yang Z, Hao J, Huang S, Yang W, Zhu Z, Tian L, Lu Y, Xiang H, Liu S (2020) Acute effects of air pollution on the incidence of hand, foot, and mouth disease in Wuhan, China. Atmos Environ 225:117358. https://doi.org/10.1016/j.atmosenv.2020.117358

Yao T-T, Qian J-D, Zhu W-Y, Wang G-Q (2020a) A systematic review of lopinavir therapy for SARS coronavirus and MERS coronavirus-a possible reference for coronavirus disease-19 treatment option. J Med Virol 92:556-563. https://doi.org/10.1002/jmv. 25729

Yao Y, Pan J, Wang W, Liu Z, Kan H, Qiu Y, Meng X, Wang W (2020b) Association of particulate matter pollution and case fatality rate of COVID-19 in 49 Chinese cities. Sci Total Environ 741:140396. https://doi.org/10.1016/j.scitotenv.2020.140396

Ye R, Liu Z (2019) ACE2 exhibits protective effects against LPSinduced acute lung injury in mice by inhibiting the LPS-TLR4 pathway. Exp Mol Pathol 113:104350. https://doi.org/10.1016/j. yexmp.2019.104350

Ye Q, Fu J, Mao J, Shang S (2016) Haze is a risk factor contributing to the rapid spread of respiratory syncytial virus in children. Environ Sci Pollut Res 23:20178-20185. https://doi.org/10.1007/ s11356-016-7228-6

Zarasvandi A, Carranza EJM, Moore F, Rastmanesh F (2011) Spatio-temporal occurrences and mineralogical-geochemical characteristics of airborne dusts in Khuzestan Province (southwestern Iran). J Geochem Explor 111:138-151. https://doi.org/ 10.1016/J.GEXPLO.2011.04.004

Zhu W, Xu X, Zheng J, Yan P, Wang Y, Cai W (2018) The characteristics of abnormal wintertime pollution events in the Jing-Jin-Ji region and its relationships with meteorological factors. Sci Total Environ 626:887-898. https://doi.org/10.1016/j.scitotenv.2018. 01.083

Zhu Y, Xie J, Huang F, Cao L (2020) Association between short-term exposure to air pollution and COVID-19 infection: evidence from China. Sci Total Environ 727:138704. https://doi.org/10.1016/j. scitotenv.2020.138704

Zoran MA, Savastru RS, Savastru DM, Tautan MN (2020) Assessing the relationship between surface levels of PM2.5 and PM10 particulate matter impact on COVID-19 in Milan, Italy. Sci Total Environ 738:139825. https://doi.org/10.1016/j.scitotenv.2020. 139825

Publisher's note Springer Nature remains neutral with regard to jurisdictional claims in published maps and institutional affiliations. 